\title{
Exercise improves growth, alters physiological performance and gene expression in common carp (Cyprinus carpio)
}

\author{
Jyotsna Shrivastava $^{\mathrm{a}, *}$, Božidar Rašković ${ }^{\mathrm{b}}$, Ronny Blust ${ }^{\mathrm{a}}$, Gudrun De Boeck ${ }^{\mathrm{a}}$

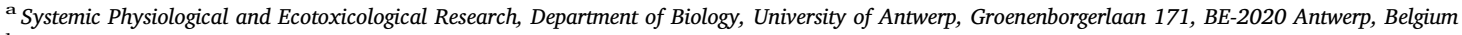 \\ ${ }^{\mathrm{b}}$ Institute of Animal Sciences, Faculty of Agriculture, University of Belgrade, Nemanjina 6, Zemun, 11080 Belgrade, Serbia
}

\section{A R T I C L E I N F O}

\section{Keywords:}

Exercise

Growth

Metabolism

Energy budget

Trancriptomics

Growth hormone

Insulin-like growth factor I

\begin{abstract}
A B S T R A C T
It has been suggested that induced swimming has the potential to improve the growth performance of fish. We tested this hypothesis by measuring growth, metabolic efficiency and physiological capacity of common carp (Cyprinus carpio). Fish were swum at different exercise regimes: 0.0 (control), 1.5 and 2.5 body lengths per second (BL/s) in $1600 \mathrm{~L}$ recirculating raceways for 4 weeks. The results showed a significant increase in weight gain, specific growth rate, improved feed conversion efficiency, and a higher hepatosomatic index for $2.5 \mathrm{BL} / \mathrm{s}$ exercised fish compared to control. Glycogen, protein and lipid energy stores in hepatic and muscular tissue showed limited differences among experimental groups. Likewise, plasma $\left[\mathrm{Na}^{+}\right],\left[\mathrm{K}^{+}\right]$and $\left[\mathrm{Cl}^{-}\right]$remained stable at all swimming regimes. Expression of genes controlling energy metabolism and growth (IGF-I axis, cytochrome oxidase) and stress response (cortisol receptor, heat shock protein 70) revealed clear regulatory roles as the mRNA transcript levels of IGF-I and growth hormone receptors in hepatic tissue were up-regulated in fish exercised for 3-4 weeks at $2.5 \mathrm{BL} / \mathrm{s}$. Oxygen consumption rate and swimming performance $\left(\mathrm{U}_{\text {crit }}\right)$ for each experimental group were evaluated in parallel in Blazka-type swim-tunnels (3.9 L) and showed no training effect while prolonged swimming at 1.5 and $2.5 \mathrm{BL} / \mathrm{s}$ facilitated ammonia excretion and prevented build-up of plasma ammonia. Overall, these data suggest that sustained exercise at $2.5 \mathrm{BL} / \mathrm{s}$ enhanced growth and physiological fitness without compromising energy metabolism or ion-regulation. Our study provides a prospective of implementing exercise as a tool to increase fish production efficiency in commercial aquaculture systems.
\end{abstract}

\section{Introduction}

The demand of fish for human consumption as well as for feed industry steadily increased during the last 70 years (Béné et al., 2015; Blanchard et al., 2017). Aquaculture can fill this demand, but there is an increasing need to improve sustainable practices. This can be achieved by optimizing conditions for fish growth and improved feeding efficiencies. Current intensive fish culture conditions rely heavily on high stocking density and often do not allow fish to fully perform their natural swimming behavior. Therefore, farmed fish generally lack the physiological benefits of swimming compared to their wild counterparts (Palstra et al., 2008, 2015; Palstra and Planas, 2011). In this context, induction of exercise can be a potential strategy to enhance fish growth and fitness (Palstra and Planas, 2011). A number of studies have suggested that induced swimming can improve growth and feed conversion efficiency of cultured fish species (Davison, 1989; Palstra and Planas, 2011; Davison and Herbert, 2013). Nevertheless, most studies have been conducted on salmonid fish. For example, sustained exercise resulted in augmented growth in: brown trout (Salmo trutta; Davison and Goldspink, 1977), rainbow trout (Oncorhynchus mykiss; Walker and Emerson, 1978; Nahhas et al., 1982; Houlihan and Laurent, 1987), Atlantic salmon (Salmo salar; Kuipers, 1982; Totland et al., 1987), Arctic charr (Salvelinus alpinus; Christiansen et al., 1989; Christiansen and Jobling, 1990) and brook trout (Salvelinus fontinalis; Leon, 1986; East and Magnan, 1987). Exercise-induced growth has also been reported for non-salmonids such as gilthead seabream (Sparus aurata; Ibarz et al., 2011; Sánchez-Gurmaches et al., 2013), striped bass (Morone saxatilis; Young and Cech Jr, 1993), qingbo (Spinibarbus sinensis; Li et al., 2013), hapuku (Polyprion oxygeneios; Khan et al., 2014), pacu (Piaractus mesopotamicus; Nunes et al., 2013), zebrafish (Danio rerio; Palstra et al., 2010) and yellow tail kingfish (Seriola lalandi; Brown et al., 2011; Palstra et al., 2015).

Exercise-mediated growth is optimal at swimming speeds where fish mobilize the maximum of energy for growth, while minimizing energy loss for other biological processes. It is anticipated that an optimum swimming speed $\left(\mathrm{U}_{\mathrm{opt}}\right)$ window exists when the energy cost for

\footnotetext{
* Corresponding author.

E-mail address: jyotsna.ua@gmail.com (J. Shrivastava).
} 
swimming is lowest whilst the energetic efficiency for growth rate, food conversion efficiency, protein turnover, lipid metabolism and physiological capacity are highest (Davison, 1997; Palstra et al., 2010, 2015; Palstra and Planas, 2011; Davison and Herbert, 2013). At swimming speeds below $\mathrm{U}_{\mathrm{opt}}$, energy expenditure increasingly fuels higher spontaneous activity such as aggression (McEwen and Wingfield, 2003; Palstra et al., 2010), while at speeds higher than $U_{\text {opt }}$ swimming becomes unsustainable and stressful and induces a shift to anaerobic metabolism, creating an oxygen debt and eventually causing fatigue (Davison, 1997; McEwen and Wingfield, 2003; Palstra et al., 2015). For the majority of studied fish species, $U_{\text {opt }}$ is identical to the exercise regime that promotes optimal growth $\left(\mathrm{ER}_{\mathrm{opt} \text { growth }}\right)$. This is because exercise-related increments in growth are most likely accommodated within the confines of the available metabolic scope where the metabolic costs of transport are minimized. Published results indicate that rearing salmonids at the $\mathrm{ER}_{\text {opt growth }}$ value, averaging 1.0-1.7 body length/second $(\mathrm{BL} / \mathrm{s})$, improves growth performance in Atlantic salmon, brown trout, brook trout and rainbow trout (Jørgensen and Jobling, 1993; Davison and Herbert, 2013). Likewise, Yogata and Oku (2000) documented that $1.6 \mathrm{BL} / \mathrm{s}$ as the $\mathrm{ER}_{\text {opt growth }}$ for yellowtail (Seriola quinqueradiata) fingerlings. These findings recommend that for the use of beneficial exercise-induced growth, an in-depth understanding of $\mathrm{ER}_{\mathrm{opt} \text { growth }}$ specific for the targeted culture species is necessary. Furthermore, it also remains largely unknown whether training can promote swimming performance of fish, which is often determined by measuring critical swimming speed $\left(\mathrm{U}_{\text {crit }}\right)$.

Despite of these reports on the growth promoting effects of exercise, the underlying mechanisms by which exercise facilitates growth are not fully understood. Although growth hormone (GH) and insulin growth factor (IGF-I) play a main regulatory role in fish nutrition, metabolism, and growth (Navarro et al., 2006; Reinecke et al., 2006), only limited information is available on the endocrine GH/IGF-I axis signaling pathways that mediate the effect of exercise on growth (Azuma et al., 2002; Blasco et al., 2015). In addition, growth is achieved by the coordinated action of many physiological and biochemical pathways which in turn are controlled at the level of transcription. In this context, it has been shown that expression of particular genes involved in the growth and developmental regulation are induced in response to swimming exercise (Magnoni et al., 2013; Palstra et al., 2013).

Ammonia is the principal waste product of fish metabolism that is typically eliminated across the gills via $\mathrm{NH}_{3}$ diffusion, either directly or facilitated by Rhesus (Rh) glycoproteins (Nakada et al., 2007; Nawata et al., 2007) with additional ' $\mathrm{Na}^{+} / \mathrm{NH}_{4}{ }^{+}$exchange' (Wright and Wood, 2009). Ammonia accumulates easily in fish blood to a toxic level if it is not excreted efficiently, and this can affect swimming performance (Shingles et al., 2001; Wicks et al., 2002; McKenzie et al., 2008; Tudorache et al., 2008a; Sinha et al., 2012a). To facilitate ammonia excretion and to meet the increased oxygen demand, swimming induces increased ventilation rates and branchial blood perfusion, thus promoting gill permeability for gas and ion exchange (Gallaugher et al., 2001; Zhang et al., 2011, 2015). On the other hand, increased ventilation and swimming can also result in ion losses when compared to resting fish (Van Dijk et al., 1993), a process known as the osmo-respiratory compromise (Onukwufor and Wood, 2018). In this regard, fish swimming at speeds enabling $\mathrm{ER}_{\text {opt growth }}$ should also control ammonia elimination and ion homeostasis.

In order to test and validate the proposed model of improved exercise-induced growth performance, we chose common carp (Cyprinus carpio). This species is widely distributed throughout the world, with total annual production of 4.16 million tons, and it is ranked as third most cultured fish species worldwide (FAO, 2016). In contrast to salmonids, common carp is found in still or slowly moving water, which indicates that continuous exercise is not part of their daily routine. It would be interesting to see whether exercise will also induce improved growth in species with a more sluggish life style. So far, there is no evidence that it is true for common carp (Martin and Johnston, 2006;
He et al., 2013). Martin and Johnston (2006) documented that in common carp endurance swimming is a powerful stimulus for proliferation of myonuclei and hyperthrophy of slow-twitch muscle fibers, but at the same time, fish growth was inhibited. Since the observed effects can strongly depend on the imposed swimming regime, the aim of this study was to use different swimming regimes to test the hypothesis that growth of common carp will be stimulated if they are subjected to sustained swimming. This will be achieved by evaluating growth and swimming performance, aerobic metabolism including energy budgets in muscle and liver, ammonia and ion homeostasis and the expression pattern of growth and stress related genes at different swimming speeds.

To achieve our goals, we measured: (i) growth performance by quantifying weight gain (\%), specific growth rate (SGR) and feed conversion ratio (FCR); (ii) expression dynamics of insulin-like growth factor I (IGF-I), somatolactin, growth hormone (GH) and growth hormone receptor (GHR) genes involved in the control of fish growth rate; (iii) glycogen, lipid and protein levels in hepatic and muscle tissue, and the hepatosomatic index as indicators of available energy stores; (iv) oxygen consumption rate and $\mathrm{U}_{\text {crit }}$ as prime markers of aerobic metabolism and swimming performance respectively; (v) ammonia dynamics by quantifying ammonia excretion rate, its accumulation in plasma and the expression pattern of ammonia transporters (Rh glycoproteins); (vi) ion status by determining ion $\left(\mathrm{Na}^{+}, \mathrm{K}^{+}, \mathrm{Cl}^{-}\right.$) levels in plasma, and finally (vii) the expression of the cortisol receptor (CR), heat shock protein 70 (HSP70) and cytochrome oxidase (COI) as candidate genes for stress responses.

\section{Materials and methods}

\subsection{Experimental design}

Common carp juveniles ( 9 months old) were used for the present experiment. Fish were purchased from Wageningen University, The Netherlands. Prior to the start of the experiment, fish were acclimatized for approximately 2 months in a $1000 \mathrm{~L}$ flow-through holding tank (tap water; temperature $21 \pm 1{ }^{\circ} \mathrm{C}$; pH 7.6; dissolved oxygen > 6.5 mg/L; natural photoperiod) located at mesocosm facility of the Systemic Physiological and Eco-toxicological Research (SPHERE), University of Antwerp, Belgium.

After the acclimation period, 300 fish (body mass $=4.02-4.88 \mathrm{~g}$; $\mathrm{BL}=5.9-6.8 \mathrm{~cm})$ from the holding tank were divided randomly and equally $(N=100)$ into three raceway swimming flumes in which the experiments were conducted. Raceways with a volume of $1600 \mathrm{~L}$ $(4.30 \times 0.95 \times 3.95 \mathrm{~m})$, were located in the same mesocosm facility as the holding tanks, and provided with the same water conditions and photoperiod. The fish were allowed to adjust to their new environment for at least $6 \mathrm{~h}$ with no directional flow. Once swimming behavior appeared normal, flow speeds in the raceways were increased slowly towards three exercise training speeds which were then maintained constantly. Speeds maintained were: 0 (resting or control group), 1.5 and $2.5 \mathrm{BL} / \mathrm{s}$.

Each of these raceways was connected to a recirculation pump, UVVarioPress filter (Dutch Water Tech, Netherlands), bio-filter with aeration section and an automated heat exchanger which regulated water temperature to $21^{\circ} \mathrm{C}$. Fish were hand fed with commercial pellets ('Hikari Staple' Kyorin Food Ind. Ltd., Japan; Protein 54\%, Lipids 15\%) at $3 \%$ of their total body mass daily. Feed quantity was adjusted according to fish mean body mass weekly. To feed the fish, the water circulation was stopped for half an hour each morning ensuring fish would ingest all delivered pellets. The exercise protocol lasted for 4 weeks, and water parameters were measured daily: $\mathrm{pH} 7.4 \pm 0.2$, dissolved oxygen $\quad 6.9-7.4 \mathrm{mg} / \mathrm{L}, \quad \mathrm{NH}_{3} \quad 0.006-0.009 \mathrm{mM}$, nitrite 0.0015-0.0021 mM, nitrate 0.015-0.042 mM, Ca ${ }^{2+} 0.8-1.0 \mathrm{mM}, \mathrm{Mg}^{2+}$ 0.19-0.21 mM, Na ${ }^{+} 1.2-1.4 \mathrm{mM}, \mathrm{K}^{+} 0.09-0.10 \mathrm{mM}, \mathrm{Cl}^{-} 0.9-1.2 \mathrm{mM}$, titratable alkalinity $1.6-1.8 \mathrm{mM}$ and hardness $226 \mathrm{mg} \mathrm{CaCO}_{3} / \mathrm{L}$ ). 
All animal experiments were approved by the local ethics committee (University of Antwerp), and conducted according to the guidelines of the Federation of European Laboratory Animal Science Associations.

\subsection{Oxygen consumption measurements in individual respirometers}

At the end of 1st, 2nd, 3rd and 4th week of experiment, 8 fish from each raceway group were randomly sampled, measured for body weight (g) and body length $(\mathrm{cm})$, and placed in a set-up of eight small scale Blazka-style swimming respirometers, one fish per respirometer. The fish were placed in the tunnel $12 \mathrm{~h}$ prior to start of the measurement (the evening before) to adapt themselves to new environmental conditions as well as to avoid the effect of handling stress. Water speed was set at $10 \mathrm{~cm} / \mathrm{s}$ which allowed the fish to orient themselves against the water current and swim gently overnight. Each of these Blazka-style swimming respirometers had a volume of $3.9 \mathrm{~L}$ [outer tunnel $=50 \times 11 \mathrm{~cm} \quad$ (length $\times$ diameter) and inner tunnel $=35 \times 6 \mathrm{~cm}$ (length $\times$ diameter) $]$ which were placed per 2 in a recirculating system containing approximately $180 \mathrm{~L}$ of water.

At the start of oxygen consumption measurements, initial water samples were collected from each respirometer. Water circulation through the respirometers was cut off, air bubbles were removed through the outlets without stressing the fish, the oxygen electrodes (WTW OxiCal-SL, Germany), one in each respirometer, were inserted and the system was made airtight so that water leakage from the respirometers was disabled. Dissolved oxygen concentrations in the water were recorded until oxygen levels had dropped below $70 \%$ of the initial value. At that point, final water samples were collected to measure ammonia excretion by fish. Oxygen consumption rate was calculated according to formulae:

Oxygen consumption rate $=\frac{(A-B) \times V \times T \times 1000}{M \times W}$

where (A-B) is the decrease of the $\mathrm{O}_{2}$ content between the start (A) and the end (B) of measuring period ( $\mathrm{mg} / \mathrm{L}), \mathrm{M}$ is the molecular weight of oxygen (32), $\mathrm{W}$ is the weight of the fish $(\mathrm{g}), \mathrm{T}$ is the time interval (h) and $\mathrm{V}$ is the total water volume in the respirometer $(3.9 \mathrm{~L})$.

\subsection{Ammonia excretion rate}

Water total ammonia levels were determined using the salicylate-hypochlorite method (Verdouw et al., 1978). Ammonia excretion rates $(\mu \mathrm{mol} / \mathrm{kg} / \mathrm{h})$ per fish were calculated as:

Ammonia excretion rate $=\frac{\left(\mathrm{Amm}_{\mathrm{i}}-\mathrm{Amm}_{\mathrm{f}}\right) \times \mathrm{V}}{\mathrm{T} \times \mathrm{M}}$

where $[\mathrm{Amm}]_{\mathrm{i}}$ and $[\mathrm{Amm}]_{\mathrm{f}}$ are the initial and final concentrations of ammonia in the water (in $\mu$ moles $/ \mathrm{L}$ ) obtained from comparison to a standard curve. $\mathrm{V}$ indicates volume of water (L), T -time interval (h), and $\mathrm{M}$-body mass (kg).

\subsection{Determination of critical swimming speed}

After completion of the oxygen consumption trial, the flow-through was restored and fish were left at a water flow rate of $5-10 \mathrm{~cm} / \mathrm{s}$ to ensure sufficient mixing of the water and $\mathrm{O}_{2}$ in the tunnel. After at least an hour of resting phase, a test for determining critical swimming speed $\left(\mathrm{U}_{\text {crit }}\right)$ was conducted. Water velocity was changed in increments of $5 \mathrm{~cm} / \mathrm{s}$ at $20 \mathrm{~min}$ intervals, until fish became fatigued. Fish were considered fatigued once they impinged on the rear screen and would not swim for $30 \mathrm{~s}$ after the water velocity was temporarily lowered and then returned to the speed at which exhaustion had occurred. $\mathrm{U}_{\text {crit }}$ was calculated according to the equation given by Brett (1964):

$U_{\text {crit }}=U_{i}+\left[U_{i i}\left(\frac{T_{i}}{T_{i i}}\right)\right]$ where $U_{i}$ is the highest velocity maintained for the whole interval, $U_{i i}$ is the velocity increment $(5 \mathrm{~cm} / \mathrm{s}), T_{i}$ is the time elapsed at fatigue velocity, and $\mathrm{T}_{\mathrm{ii}}$ is the interval time $(20 \mathrm{~min})$. The absolute values $(\mathrm{cm} / \mathrm{s})$ were converted to relative swimming speeds in $\mathrm{BL} / \mathrm{s}$ by factoring the absolute values by the fork length of the fish.

\subsection{Sampling procedure}

All fish from each experimental group were individually weighed at the beginning and the end of the experiment, while at the end of 2nd and 3rd week, a sample of 20 fish were weighed and immediately returned to the raceway. Growth performance of juveniles was evaluated in terms of weight gain based on following standard formula:

Weight gain $(\%)=\left(\left(\mathrm{W}_{\mathrm{t}}-\mathrm{W}_{\mathrm{o}}\right) / \mathrm{W}_{\mathrm{o}}\right) \times 100$

Specific growth rate $(\mathrm{SGR})=\left(\left(\ln \mathrm{W}_{\mathrm{t}}-\ln \mathrm{W}_{\mathrm{o}}\right) /\right.$ number of weeks $) \times 100$

Feed conversion ratio $(\mathrm{FCR})=\mathrm{Dd} /\left(\mathrm{W}_{\mathrm{t}}-\mathrm{W}_{\mathrm{o}}\right)$

where $\mathrm{W}_{\mathrm{t}}$ is the final body weight $(\mathrm{g}), \mathrm{W}_{\mathrm{o}}$ is the initial body weight $(\mathrm{g})$ and Dd is the quantity of feed consumed $(\mathrm{g})$.

For sampling, another 8 fish were randomly sampled from each raceway, at the end of each week, anesthetized using an overdose of neutralized MS222 (ethyl 3-aminobenzoate methanesulfonic acid, $1 \mathrm{~g}$ / L, Acros Organics, Geel, Belgium), blotted dry, weighed and measured for fork length. Then, a blood sample was collected from the caudal blood vessel using a heparinized (2500 units/mL lithium heparin, Sigma) $1 \mathrm{~mL}$ syringe with 23-gauge needle. Blood was immediately centrifuged (for $1 \mathrm{~min}$ at the speed of $16,000 \mathrm{rpm}$ at $4^{\circ} \mathrm{C}$ ), and aliquots of plasma were frozen in liquid nitrogen and stored at $-80^{\circ} \mathrm{C}$ for determination of plasma ammonia concentration and ions. Fish were subsequently dissected on ice, the liver, gills and muscle tissue were removed, frozen in liquid nitrogen, and stored at $-80{ }^{\circ} \mathrm{C}$ for further biochemical assays. In addition, one portion of liver and gills was added to five volumes of RNAlater (Qiagen, Hilden, Germany) and stored at $4{ }^{\circ} \mathrm{C}$ for later molecular analysis.

\subsection{Analytical techniques}

Total ammonia level in plasma $\left(\mathrm{T}_{\mathrm{Amm}}\right)$ was determined using an enzymatic kit (R-Biopharm AG, Darmstadt, Germany). Plasma $\left[\mathrm{Na}^{+}\right]$, $\left[\mathrm{Cl}^{-}\right]$and $\left[\mathrm{K}^{+}\right]$were analyzed using an AVL 9180 Electrolyte Analyzer (AVL, Roche Diagnostics, Belgium). Samples of liver and muscle were analyzed for protein content by Bradford's method (Bradford, 1976), glycogen content by using the anthrone reagent (Roe and Dailey, 1966) and lipid content was measured according to Bligh and Dyer (1959). Muscle tissue was dissected dorsally from the lateral line for determination of the muscle water content (MWC). Traces of water and blood on the excised muscle were wiped off with tissue paper. MWC was determined as the percentage of weight loss after drying at $100{ }^{\circ} \mathrm{C}$ for 2 days. Whole liver mass was recorded and hepatosomatic index (HSI) was calculated as $\mathrm{HSI}=(\mathrm{LM} / \mathrm{BW}) \times 100$, where $\mathrm{LM}$ is referred as liver mass and BW is the body weight.

\subsection{Molecular analyses}

\subsubsection{RNA extraction}

Total RNA was isolated from the liver and gills samples using Trizol (Invitrogen, Merelbeke, Belgium) according to the manufacturer's instructions. The extracted RNA samples were DNase treated to avoid genomic DNA contamination. DNase buffer (DNase I buffer with $\mathrm{MgCl}_{2}$; Fermentas, Cambridge, UK), DNase I (Fermentas, Cambridge, UK) and RNase inhibitor (Fermentas, Cambridge,UK) were added to the isolated RNA followed by the incubation at $37^{\circ} \mathrm{C}$ for $30 \mathrm{~min}$. Phenol-chloroform extraction and washing steps with various dilutions of ethanol were then performed to remove any traces of DNA or salts. The quantity of 
Table 1

PCR primer sequences, accession numbers and calculated efficiency.

\begin{tabular}{|c|c|c|c|}
\hline Gene & Accession no. & Sequence of primer $\left(5^{\prime} \rightarrow 3^{\prime}\right)$ & Efficiency (\%) \\
\hline \multicolumn{4}{|l|}{ Growth controlling genes } \\
\hline \multirow[t]{2}{*}{ Growth hormone } & M27000 & F: TAACGACTCCTTGCCGC & 90.1 \\
\hline & & R: TCTACAGGGTGCAGTTGG & \\
\hline \multirow[t]{2}{*}{ Insulin-like growth factor-I } & AF465830 & F: GATGGCAAGTCACCTCC & 88.8 \\
\hline & & R: GACAAGAGCCAAGCCTG & \\
\hline \multirow[t]{2}{*}{ Growth hormone receptor } & AY691176 & F: GAGCAGGGGTACCAAAC & 92.4 \\
\hline & & R: GCTGTGAGGGCATATCG & \\
\hline \multirow[t]{2}{*}{ Somatolactin } & GU434163.1 & F: TCGTTACGATGACGCCC & 86.7 \\
\hline & & R: GGCGTCCTTCTTGAAGC & \\
\hline \multicolumn{4}{|l|}{ Stress representative genes } \\
\hline \multirow[t]{2}{*}{ Heat shock protein 70} & AY120894 & F: GGCAGAAAGTTTGATGACCCA & 99.6 \\
\hline & & R: GCAATCTCCTTCATCTTCACC & \\
\hline \multirow[t]{2}{*}{ Cytochrome oxidase subunit1 } & HQ536347 & F: GGAACTTAGCCCACGCA & 94.5 \\
\hline & & R: AAGCACGGATCAGACGA & \\
\hline \multirow[t]{2}{*}{ Cortisol receptor } & EF042099 & F: GTGAGACTGCAAGTGTCCAA & 93.0 \\
\hline & & R: CTCTCTCTTCACTATGGCCT & \\
\hline \multicolumn{4}{|l|}{ Ammonia transporters } \\
\hline \multirow[t]{2}{*}{ Rhbg } & JX570877 & F: TCCCAGTTTCCAGGATGTTC & 108.0 \\
\hline & & R: TGGAAAAAGCCCTGCATAAG & \\
\hline \multirow[t]{2}{*}{ Rhcg-a } & JX570878 & F: ATCCTGAACATCCTCCATGC & 84.6 \\
\hline & & R: AACTTGGCCAGAACATCCAC & \\
\hline \multirow[t]{2}{*}{ Rhcg-b } & JX570879 & F: CACAAAGCCACACACAGTCC & 106.8 \\
\hline & & R: TCTTTTTCTCGCCGTTCTTG & \\
\hline \multirow[t]{2}{*}{ NHE-3 } & Bradshaw et al., 2012 & F: GTGTCATTTGGAGGCTCGTT & 89.0 \\
\hline & & R: ATCCATGTTGGCGGTAATGT & \\
\hline \multicolumn{4}{|l|}{ Reference genes } \\
\hline \multirow[t]{2}{*}{$\beta$ actin } & M24113.1 & F: AGCTAGGCCTTGAGCTAT & 92.2 \\
\hline & & R: CCTGCTTGCTAATCCACA & \\
\hline \multirow[t]{2}{*}{ Elongation factor $1 \alpha$} & AF485331.1 & F: TGGAGATGCTGCCATTGT & 100.8 \\
\hline & & R: TGCAGACTTCGTGACCTT & \\
\hline \multirow[t]{2}{*}{ Glyceraldehyde-3-phosphate dehydrogenase } & AJ870982.1 & F: ATCTGACGGTCCGTCT & 95.0 \\
\hline & & R: CCAGCACCGGCATCAAA & \\
\hline
\end{tabular}

The accession number refers to the registered sequence used from Genbank. F: forward, R: reverse.

RNA was evaluated using Nano-Drop spectrophotometry (Nano Drop Technologies, Wilmington, DE, USA). The purity was checked by measuring the OD260/OD280 absorption ratio ( $>1.95)$.

\subsubsection{Real-time PCR}

For quantitative real-time PCR (qPCR), a starting amount of $1 \mu \mathrm{g}$ RNA was transcribed into first-strand cDNA using the Revert Aid $\mathrm{H}$ minus First strand cDNA synthesis kit (Fermentas, Cambridge, UK). mRNA expression of growth hormone (GH), insulin-like growth factor-I (IGF-I), growth hormone receptor (GHR), somatolactin (SL), cortisol receptor (CR), heat shock protein 70 (HSP 70) and cytochrome oxidase subunit 1 (COI) in the hepatic tissue while $\mathrm{Na}^{+} / \mathrm{H}^{+}$-exchanger (NHE3), Rhcg-a, Rhcg-b, Rhbg in the gill tissue, were quantified by qPCR using the specific primers listed in Table 1 . The primer sequences were adopted from Sinha et al. (2012b, 2013), with the exception of NHE-3 (Bradshaw et al., 2012). qPCR analyses were performed on an Mx3000P QPCR System (Agilent Technologies, Belgium). Reactions containing $5 \mu \mathrm{L}$ of $5 \times$ diluted cDNA, 10 pmol each of forward and reverse primers, $0.3 \mu \mathrm{L}$ ROX dye (1:500 dilution) and $10 \mu \mathrm{L}$ Brilliant III Ultra-Fast SYBR Green qPCR Master Mix (Agilent) were performed in a four-step experimental run protocol: a denaturation program $\left(3 \mathrm{~min}\right.$ at $\left.95^{\circ} \mathrm{C}\right)$; an amplification and quantification program repeated 40 times $(15 \mathrm{~s}$ at $95^{\circ} \mathrm{C}, 20 \mathrm{~s}$ at $\left.60^{\circ} \mathrm{C}\right)$; a melting curve program $\left(60-95^{\circ} \mathrm{C}\right.$ with a heating rate of $0.10^{\circ} \mathrm{C} / \mathrm{s}$ and a continuous fluorescence measurement) and finally a cooling step. Melt curve analyses of the target genes and reference genes resulted in single products with specific melting temperatures. In addition, 'no-template' controls (i.e. with water sample) for each set of genes were also run to ensure no contamination of reagents, no primer-dimer formation, etc. Comparison of several reference genes ( $\beta$-actin, elongation factor- $1 \alpha$ 'EF1 $\alpha$ ', glyceraldehyde-3phosphate dehydrogenase (GAPDH') favoured EF1 $\alpha$ for hepatic tissue and $\beta$-actin for gills tissue as the most stable genes across the samples (20 random samples were tested) and were used as endogenous standard to calculate relative mRNA expression by the standard curve method. Standard curves for each set of primers were generated by serial dilution of a random mixture of control cDNA samples.

\subsection{Statistical analysis}

All data have been presented as mean values \pm standard error (S.E.). The normality of the data was assessed using the Shapiro-Wilk test, and homogeneity of variances using a Levene's test. For comparisons between different experimental groups a one-way analysis of variance (ANOVA) was performed followed by the least significant difference (LSD) test. Student's two-tailed $t$-test was used for single comparisons. The data were analyzed by Statistical Package for the Social Sciences (SPSS) version 20.0. A probability level of 0.05 was used for rejection of the null hypothesis.

\section{Results}

\subsection{In vivo parameters}

The weight gain (\%) augmented significantly in $2.5 \mathrm{BL} / \mathrm{s}$ exercised fish after 1, 3 and 4 weeks, with values that were respectively $78 \%, 73 \%$ and $46 \%$ higher comparing to control (Fig. 1A). However, no significant difference was seen between the control group and fish exercised at $1.5 \mathrm{BL} / \mathrm{s}$. A similar pattern was noted for SGR; relative to the control, SGR increased significantly in the fish swum at $2.5 \mathrm{BL} / \mathrm{s}$ for 1,3 and 4 weeks (Fig. 1B). Likewise, FCR for $2.5 \mathrm{BL} / \mathrm{s}$ exercised fish were $28 \%$ and $35 \%$ lower than the control respectively during 3 and 4 weeks (Fig. 1C). 

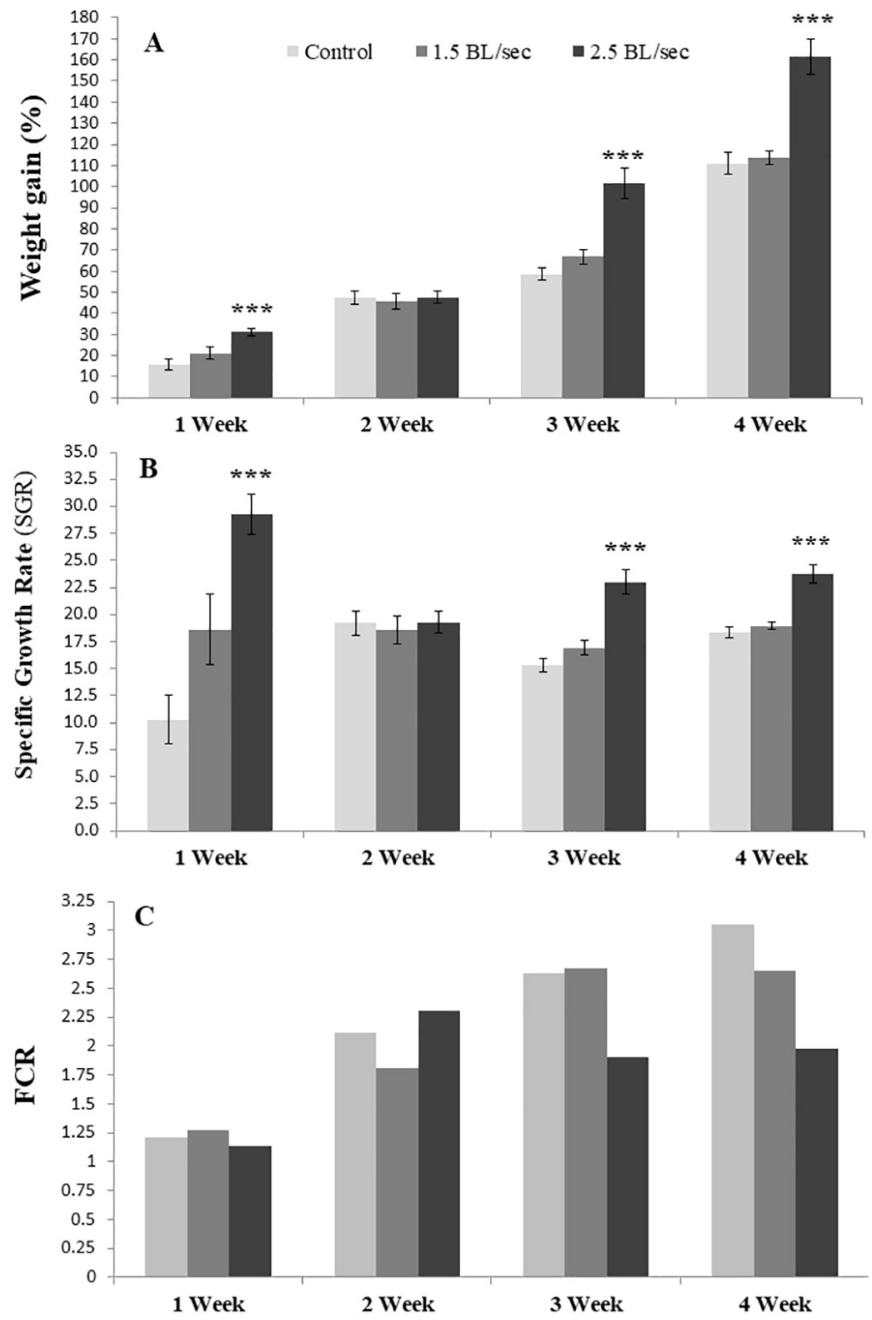

Fig. 1. The effect of different exercise regimes $(0 \mathrm{BL} / \mathrm{s}, 1.5 \mathrm{BL} / \mathrm{s}$ and $2.5 \mathrm{BL} / \mathrm{s})$ on (A) weight gain (\%) (B) SGR and (C) FCR of common carp during 4 week trial. Values are presented as mean \pm S.E. The asterisk $\left(^{*}\right)$ denotes the significant differences between control and exercised fish at the same sampling point $(* * * P<.001)$.

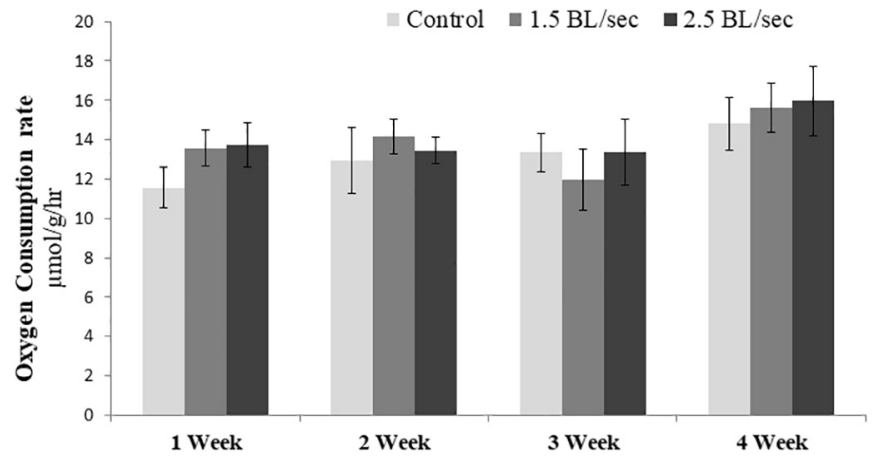

Fig. 2. Oxygen consumption rates by control and exercised fish in individual Blazka-style swimming respirometers. Values are presented as mean \pm S.E.

Overall, we observed no training effect on oxygen consumption rate or swimming capacity; the values remained statistically indifferent between the control and both swimming treatments (Fig. 2). In the present study, control fish and exercised fish swam equally well, and exercised fish showed no significant improvement in $\mathrm{U}_{\text {crit }}$ (Fig. 3). 1.5 and $2.5 \mathrm{BL} / \mathrm{s}$ showed to be approximately one-fifth and one-third of $\mathrm{U}_{\text {crit }}$ (in $\mathrm{BL} / \mathrm{s}$ ) respectively.

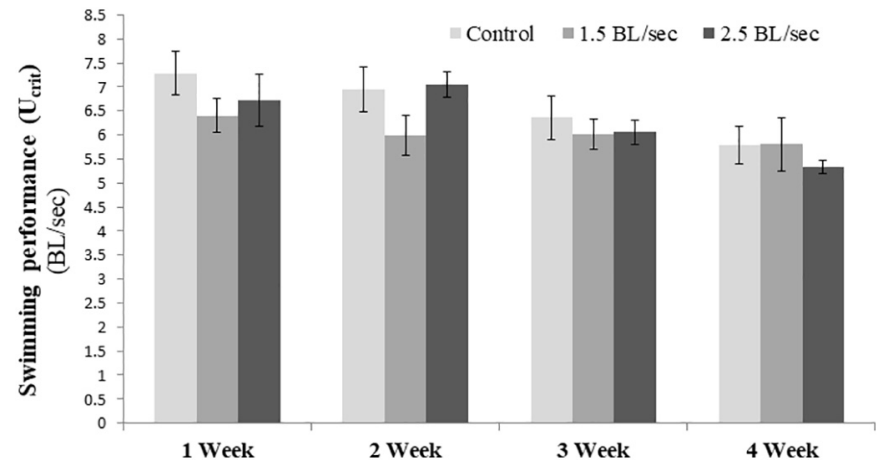

Fig. 3. Swimming performance in common carp swum at $0 \mathrm{BL} / \mathrm{s}, 1.5 \mathrm{BL} / \mathrm{s}$ and $2.5 \mathrm{BL} / \mathrm{s}$ for 4 weeks. Values are presented as mean \pm S.E.

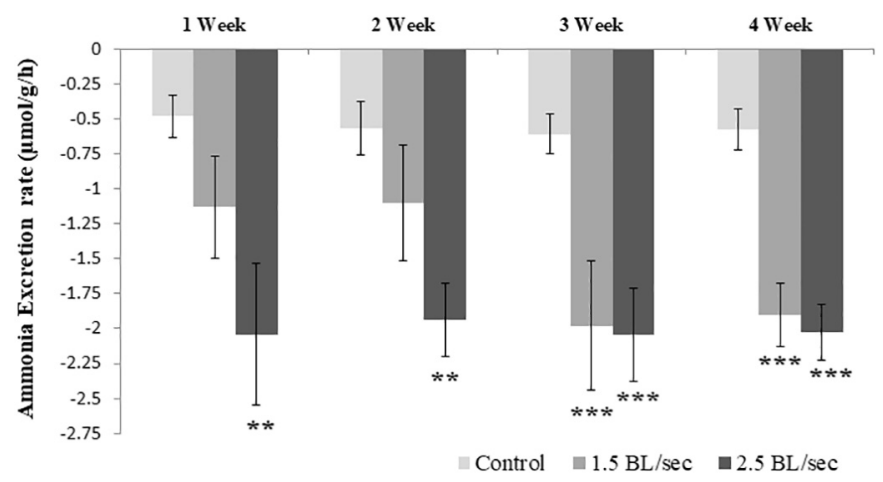

Fig. 4. Ammonia excretion rates in common carp swum at $0 \mathrm{BL} / \mathrm{s}, 1.5 \mathrm{BL} / \mathrm{s}$ and $2.5 \mathrm{BL} / \mathrm{s}$ for 4 weeks. Values are presented as mean \pm S.E. The asterisk (*) denotes the significant differences between control and exercised fish at the same sampling point $\left({ }^{* *} P<.01 ; * * * P<.001\right)$.

Swimming the fish at $1.5 \mathrm{BL} / \mathrm{s}$ induced a gradual increase in the ammonia excretion efficiency which became significant $(P<.001)$ at the end of 3rd and 4th week relative to the control (Fig. 4). Exercising the fish at $2.5 \mathrm{BL} / \mathrm{s}$ speed also had a profound effect on ammonia excretion rates, the values were considerably higher $(P<.01,0.001)$ than their respective controls in each week.

\subsection{Metabolites and ions}

No remarkable effect of exercise was observed on the level of plasma total ammonia (Table 2). $\mathrm{T}_{\mathrm{amm}}$ remained unaltered in all experimental groups irrespective of the sampling periods. In addition, the concentration of measured ions $\left(\mathrm{Na}^{+}, \mathrm{Cl}^{-}, \mathrm{K}^{+}\right)$in plasma remained unchanged (Table 2).

In $2.5 \mathrm{BL} / \mathrm{s}$ exercised fish hepatosomatic index (HSI) increased significantly by $26 \%$ relative to the control after 4 weeks (Fig. 5). HSI and muscle water content (MWC) remained stable in $1.5 \mathrm{BL} / \mathrm{s}$ group. On the contrary, in $2.5 \mathrm{BL} / \mathrm{s}$ exercised fish, the MWC declined at week 4 by $21 \%(P<.05)$ comparing to the control value (Fig. 6$)$.

A small effect of swimming speed at $2.5 \mathrm{BL} / \mathrm{s}$ was observed on the protein content in liver tissue; a significant $(P<.05)$ increment compared to the control was documented at the end of week 4 (Table 3). Despite of this increment in protein content, lipid and glycogen stores remained unchanged irrespective of exercising treatments. Likewise, glycogen, protein and lipid stores in muscle did not alter in any swimming group.

\subsection{Expression pattern of growth related hormone and receptor genes, and} ammonia transporters

Hepatic IGF-I expression was not affected in fish swimming at 
Table 2

Total ammonia $\left(\mathrm{T}_{\mathrm{amm}}\right)$ and ion concentrations in plasma $(\mathrm{mmol} / \mathrm{L})$ of common carp under experimental conditions.

\begin{tabular}{lllll}
\hline \multirow{2}{*}{ Parameters } & $\begin{array}{l}\text { Sampling } \\
\text { points }\end{array}$ & \multicolumn{3}{l}{ Group } \\
\cline { 3 - 5 } & & Control & $1.5 \mathrm{BL} / \mathrm{s}$ & $2.5 \mathrm{BL} / \mathrm{s}$ \\
\hline \multirow{2}{*}{$\mathrm{T}_{\mathrm{amm}}$} & Week 1 & $0.200 \pm 0.027$ & $0.229 \pm 0.029$ & $0.265 \pm 0.030$ \\
& Week 2 & $0.221 \pm 0.014$ & $0.214 \pm 0.027$ & $0.256 \pm 0.025$ \\
& Week 3 & $0.217 \pm 0.026$ & $0.224 \pm 0.012$ & $0.227 \pm 0.026$ \\
& Week 4 & $0.247 \pm 0.018$ & $0.241 \pm 0.017$ & $0.272 \pm 0.016$ \\
{$\left[\mathrm{Na}^{+}\right]$} & Week 1 & $93 \pm 6$ & $69 \pm 10$ & $90 \pm 7$ \\
& Week 2 & $80 \pm 7$ & $83 \pm 4$ & $93 \pm 6$ \\
& Week 3 & $90 \pm 9$ & $102 \pm 4$ & $95 \pm 5$ \\
& Week 4 & $107 \pm 7$ & $113 \pm 6$ & $100 \pm 5$ \\
{$\left[\mathrm{~K}^{+}\right]$} & Week 1 & $3.5 \pm 0.3$ & $2.9 \pm 0.3$ & $3.9 \pm 0.4$ \\
& Week 2 & $3.5 \pm 0.2$ & $3.9 \pm 0.6$ & $3.1 \pm 0.3$ \\
& Week 3 & $3.3 \pm 0.2$ & $2.9 \pm 0.2$ & $3.9 \pm 0.4$ \\
& Week 4 & $3.6 \pm 0.3$ & $3.8 \pm 0.2$ & $3.8 \pm 0.3$ \\
{$\left[\mathrm{Cl}^{-}\right]$} & Week 1 & $116.3 \pm 3.4$ & $118.7 \pm 2.7$ & $121.8 \pm 3.2$ \\
& Week 2 & $112.5 \pm 6.5$ & $117.5 \pm 4.4$ & $121.8 \pm 3.4$ \\
& Week 3 & $115.5 \pm 3.4$ & $106.0 \pm 2.5$ & $107.0 \pm 3.0$ \\
& Week 4 & $101.7 \pm 5.2$ & $106.6 \pm 3.2$ & $104.7 \pm 3.1$ \\
\hline
\end{tabular}

The values are presented as mean \pm S.E.

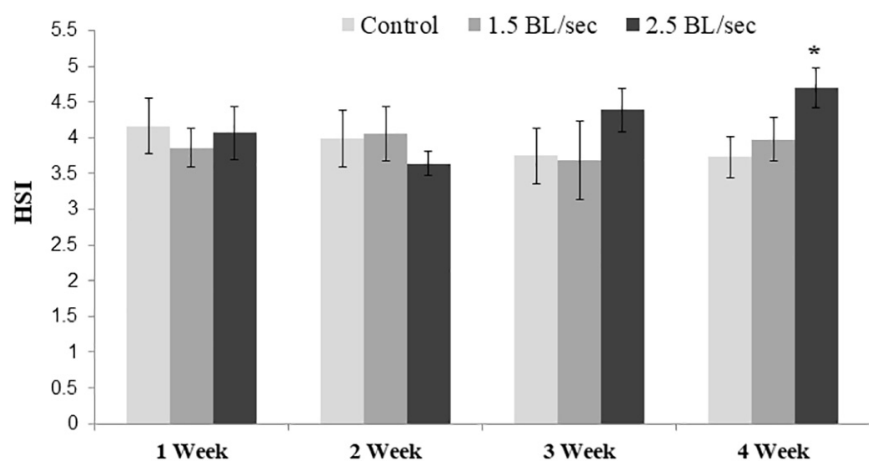

Fig. 5. Hepatosomatic index (HSI) in common carp exercised at $0 \mathrm{BL} / \mathrm{s}, 1.5 \mathrm{BL} / \mathrm{s}$ and $2.5 \mathrm{BL} / \mathrm{s}$ for 4 weeks. Values are presented as mean \pm S.E. The asterisk (*) denotes the significant differences between control and exercised fish at the same sampling point $(* P<.05)$.

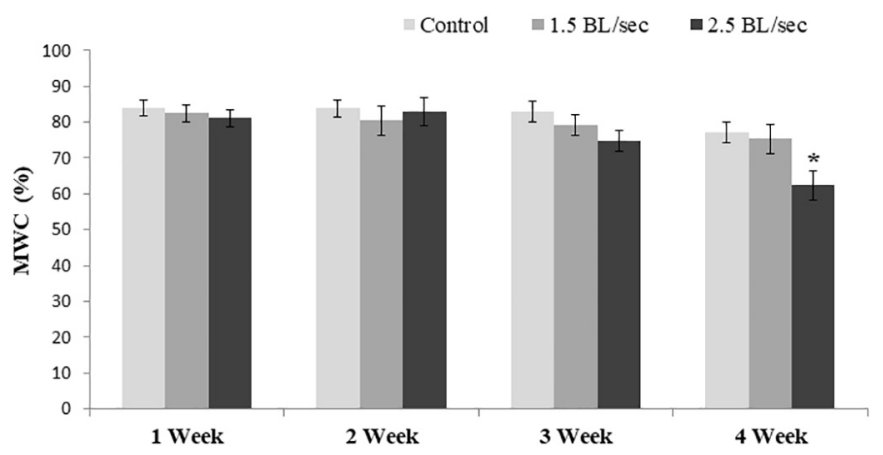

Fig. 6. Muscle water content (MWC) of common carp in control and exercised at $1.5 \mathrm{BL} / \mathrm{s}$ and $2.5 \mathrm{BL} / \mathrm{s}$ for 4 weeks. Values are presented as mean \pm S.E. The asterisk (*) denotes the significant differences between control and exercised fish at the same sampling point $\left({ }^{*} P<.05\right)$.

1.5 BL/s, however in the fish swimming at $2.5 \mathrm{BL} / \mathrm{s}$, the IGF-I mRNA expression at the end of week 3 and week 4 were up-regulated manifold $(P<.05,0.01)$ compared to the control (Fig. 7). Subjecting the fish to exercise incited an increase $(P<.05)$ in the growth hormone receptor (GHR) transcript level at both speeds (Fig. 8). This increment was detected only at the end of the experiment in fish from $1.5 \mathrm{BL} / \mathrm{s}$ group; while it was noticed from week 3 onwards until the termination of the experiment for $2.5 \mathrm{BL} / \mathrm{s}$ group $(P<.05)$. Unlike IGF-I and GHR,
Table 3

Glycogen, protein and lipid content in liver (wet tissue) and muscle (wet tissue) in common carp under different treatments.

\begin{tabular}{|c|c|c|c|c|}
\hline \multirow[t]{2}{*}{ Parameters } & \multirow{2}{*}{$\begin{array}{l}\text { Sampling } \\
\text { points }\end{array}$} & \multicolumn{3}{|l|}{ Group } \\
\hline & & Control & $1.5 \mathrm{BL} / \mathrm{s}$ & $2.5 \mathrm{BL} / \mathrm{s}$ \\
\hline \multicolumn{5}{|l|}{ Liver } \\
\hline \multirow{4}{*}{$\begin{array}{l}\text { Glycogen } \\
\quad(\mathrm{mg} / \mathrm{g})\end{array}$} & Week 1 & $162.98 \pm 17.68$ & $171.14 \pm 16.76$ & $166.40 \pm 16.72$ \\
\hline & Week 2 & $153.01 \pm 15.62$ & $150.36 \pm 15.57$ & $151.00 \pm 14.67$ \\
\hline & Week 3 & $170.06 \pm 17.71$ & $171.83 \pm 16.30$ & $182.63 \pm 12.63$ \\
\hline & Week 4 & $164.47 \pm 18.04$ & $168.52 \pm 11.47$ & $171.65 \pm 15.83$ \\
\hline \multirow{4}{*}{$\begin{array}{l}\text { Protein } \\
\qquad(\mathrm{mg} / \mathrm{g})\end{array}$} & Week 1 & $144.5 \pm 17.6$ & $151.3 \pm 21.5$ & $161.5 \pm 28.7$ \\
\hline & Week 2 & $153.0 \pm 11.3$ & $142.9 \pm 18.7$ & $143.4 \pm 13.3$ \\
\hline & Week 3 & $140.3 \pm 15.0$ & $137.8 \pm 21.6$ & $174.6 \pm 25.5$ \\
\hline & Week 4 & $140.5 \pm 16.7$ & $162.2 \pm 15.6$ & $191.3 \pm 14.3^{*}$ \\
\hline \multirow{4}{*}{$\begin{array}{l}\text { Lipid (mg/ } \\
\text { g) }\end{array}$} & Week 1 & $52.30 \pm 11.43$ & $56.61 \pm 10.18$ & $61.81 \pm 2.07$ \\
\hline & Week 2 & $50.87 \pm 5.07$ & $47.68 \pm 13.86$ & $57.51 \pm 10.96$ \\
\hline & Week 3 & $40.81 \pm 8.46$ & $43.96 \pm 11.14$ & $44.41 \pm 3.74$ \\
\hline & Week 4 & $44.45 \pm 8.59$ & $44.09 \pm 6.48$ & $41.73 \pm 5.82$ \\
\hline \multicolumn{5}{|l|}{ Muscle } \\
\hline \multirow{4}{*}{$\begin{array}{l}\text { Glycogen } \\
\quad(\mathrm{mg} / \mathrm{g})\end{array}$} & Week 1 & $8.46 \pm 1.07$ & $8.04 \pm 1.49$ & $10.54 \pm 1.97$ \\
\hline & Week 2 & $11.49 \pm 1.29$ & $12.88 \pm 1.96$ & $11.56 \pm 1.30$ \\
\hline & Week 3 & $11.80 \pm 1.97$ & $13.42 \pm 1.98$ & $13.08 \pm 1.21$ \\
\hline & Week 4 & $10.20 \pm 1.46$ & $13.42 \pm 1.46$ & $13.84 \pm 1.90$ \\
\hline \multirow{4}{*}{$\begin{array}{l}\text { Protein } \\
\qquad(\mathrm{mg} / \mathrm{g})\end{array}$} & Week 1 & $149.26 \pm 8.83$ & $148.41 \pm 7.27$ & $154.50 \pm 8.65$ \\
\hline & Week 2 & $136.63 \pm 9.31$ & $144.80 \pm 9.94$ & $135.33 \pm 9.38$ \\
\hline & Week 3 & $135.32 \pm 10.22$ & $146.43 \pm 11.73$ & $132.92 \pm 10.63$ \\
\hline & Week 4 & $143.32 \pm 9.44$ & $132.59 \pm 12.78$ & $131.91 \pm 11.19$ \\
\hline \multirow{4}{*}{$\begin{array}{l}\text { Lipid (mg/ } \\
\mathrm{g})\end{array}$} & Week 1 & $21.66 \pm 4.73$ & $23.98 \pm 2.85$ & $20.64 \pm 1.96$ \\
\hline & Week 2 & $22.96 \pm 2.93$ & $22.73 \pm 2.90$ & $20.47 \pm 5.00$ \\
\hline & Week 3 & $15.87 \pm 1.87$ & $15.99 \pm 2.35$ & $14.67 \pm 1.09$ \\
\hline & Week 4 & $15.08 \pm 2.28$ & $15.75 \pm 1.90$ & $14.21 \pm 1.21$ \\
\hline
\end{tabular}

Values are presented as mean \pm S.E. The asterisk $\left(^{*}\right)$ denotes the significant differences between control and exercised fish at the same sampling point $\left({ }^{*} P<.05\right)$

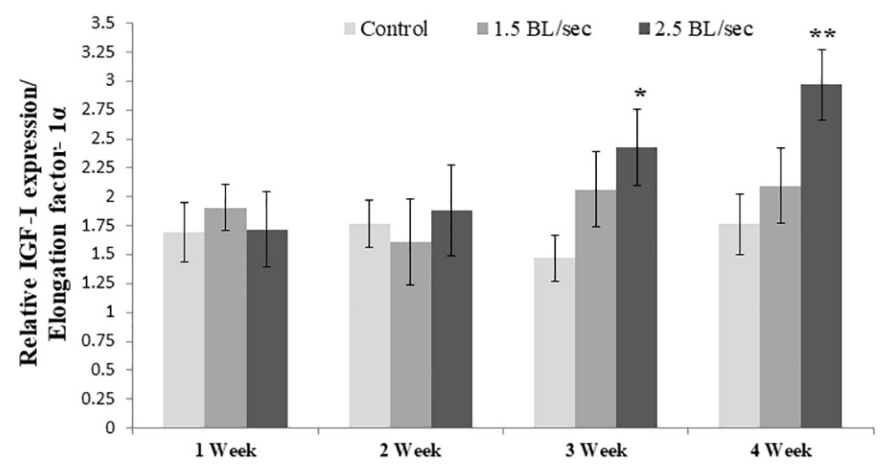

Fig. 7. Relative expression of IGF-I mRNA in liver of common carp from control and swum at $1.5 \mathrm{BL} / \mathrm{s}$ and $2.5 \mathrm{BL} / \mathrm{s}$ speeds for 4 weeks. Values are presented as mean \pm S.E. The asterisk (*) denotes the significant differences between control and exercised fish at the same sampling point $\left({ }^{*} P<.05 ;{ }^{* *} P<.01\right)$.

exercising fish at either 1.5 or $2.5 \mathrm{BL} / \mathrm{s}$ had no significant effect on growth hormone (GH) and somatolactin (SL) mRNA transcript (results not shown). No prominent effect of exercising was observed for the branchial NHE-3 (results not shown) or apical localized Rhcg isoforms (Rhcg-a and Rhcg-b) and basolateral located Rhbg mRNA expression (Fig. 9A-C). However, the expression level of Rhcg-a and Rhcg-b in $2.5 \mathrm{BL} / \mathrm{s}$ exercised fish tended to be numerically higher $(P>.05)$ than the control during 3 and 4 week of experimentation.

\subsection{Expression pattern of genes controlling stress responses}

Expression levels of HSP70 in hepatic tissue remained statistically similar between control and experimental groups (Fig. 10A). Likewise, CR mRNA level did not change considerably in course of exercising activity (Fig. 10B). We observed an effect of exercise on the COI gene 


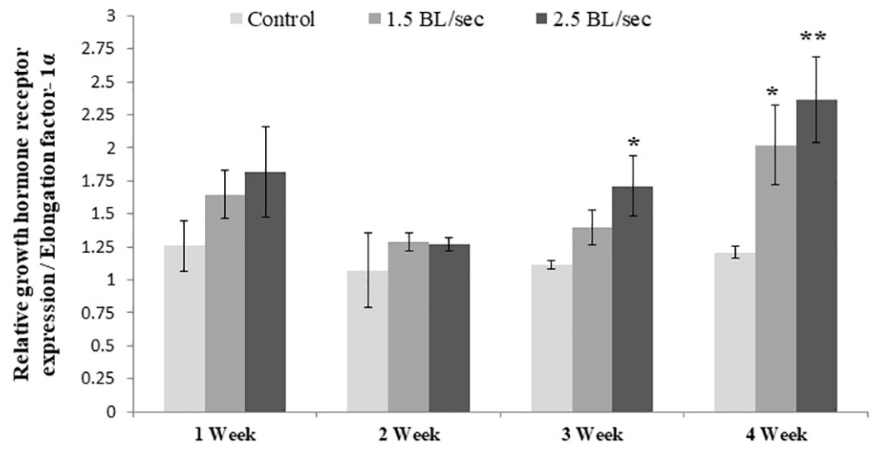

Fig. 8. Relative expression of growth hormone receptor mRNA in liver of common carp from control and swum at $1.5 \mathrm{BL} / \mathrm{s}$ and $2.5 \mathrm{BL} / \mathrm{s}$ speeds for 4 weeks. Values are presented as mean \pm S.E. The asterisk $(*)$ denotes the significant differences between control and exercised fish at the same sampling point $\left({ }^{*} P<.05 ;{ }^{* *} P<.01\right)$.
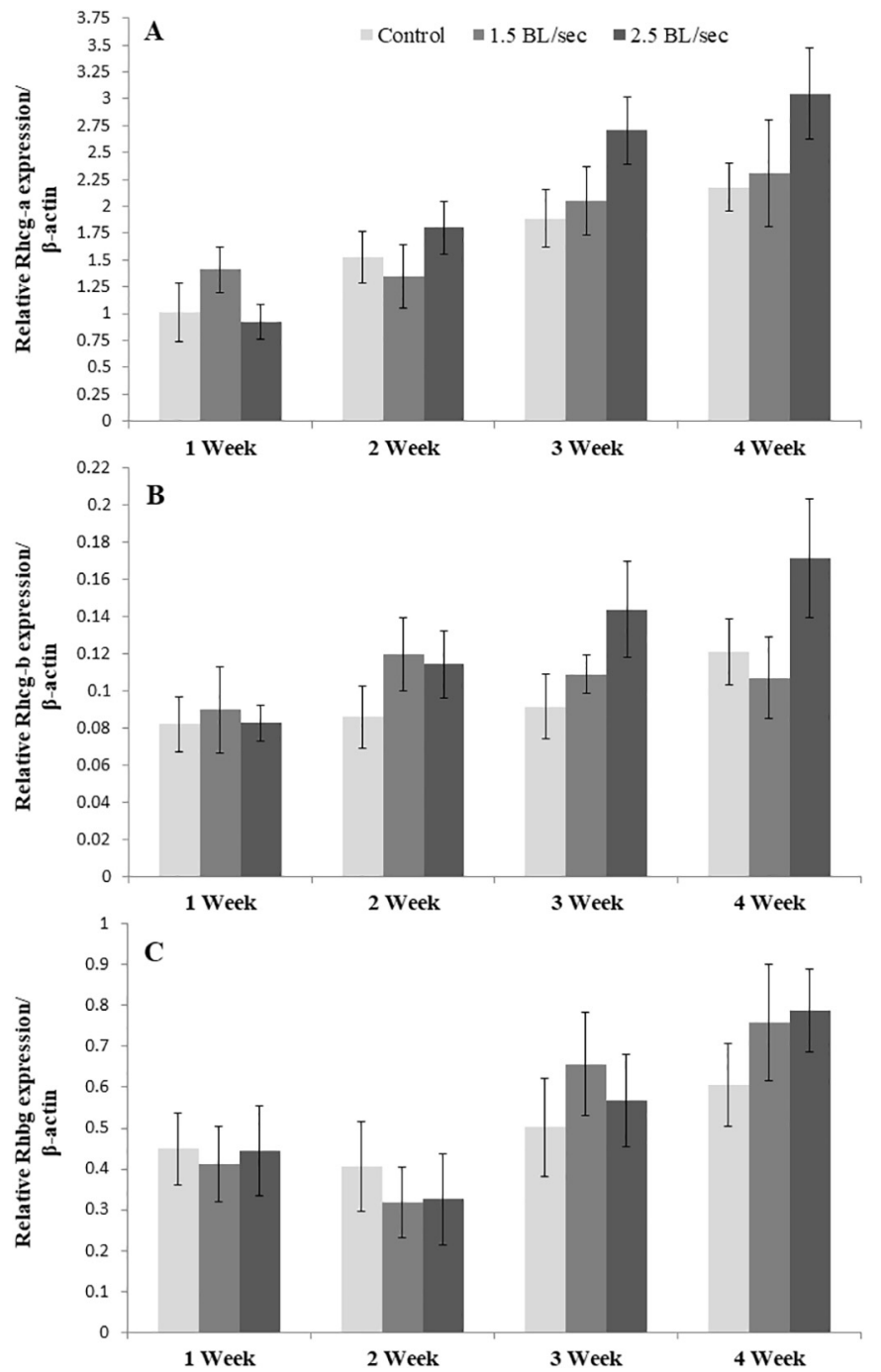

Fig. 9. Relative expression of (A) Rhcg-a (B) Rhcg-b and (C) Rhbg mRNA in the gills of common carp from control and swum at $1.5 \mathrm{BL} / \mathrm{s}$ and $2.5 \mathrm{BL} / \mathrm{s}$ speeds for 4 weeks.
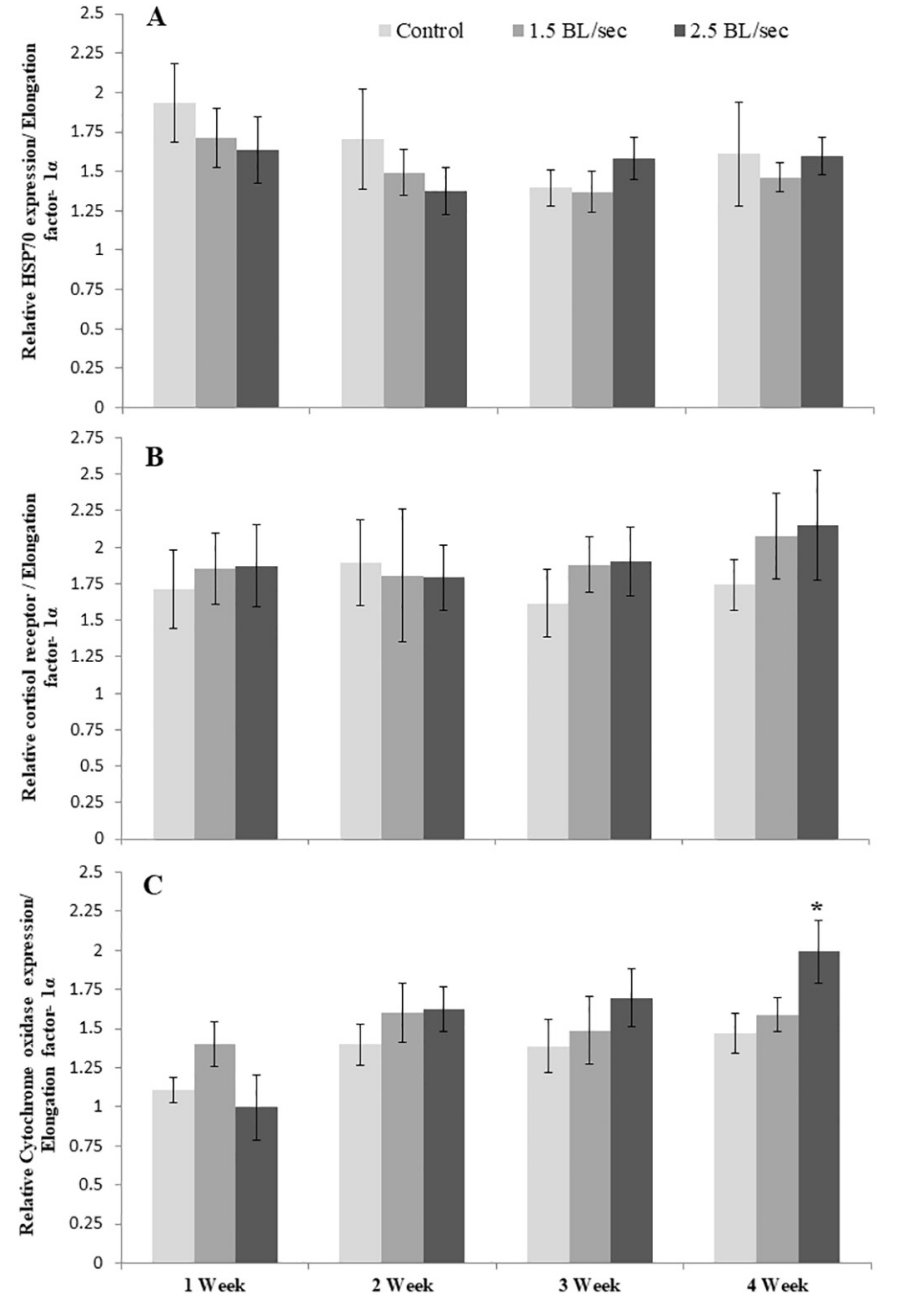

Fig. 10. Relative expression of (A) HSP 70 (B) cortisol receptor and (C) cytochrome oxidase mRNA in liver of common carp from control and swum at $1.5 \mathrm{BL} / \mathrm{s}$ and $2.5 \mathrm{BL} / \mathrm{s}$ speeds for 4 weeks. Values are presented as mean \pm S.E. The asterisk (*) denotes the significant differences between control and exercised fish at the same sampling point $\left({ }^{*} P<.05\right)$.

expression, the transcript level was significantly higher in fish exercised for 4 weeks at $2.5 \mathrm{BL} / \mathrm{s}$ (Fig. 10C).

\section{Discussion}

\subsection{Applicability of exercise to enhance growth performance}

As already pointed in the introduction, swimming activity has been demonstrated to have a major effect on growth performance and metabolism for a number of fish species. Therefore, we focused on determining if an exercise regime for optimal growth exists in common carp. We have shown that subjecting the fish to a swimming regime of $2.5 \mathrm{BL} / \mathrm{s}$ resulted in increased growth and improved feed conversion efficiency as the food conversion ratio indicated that less food was needed to support the observed faster growth. Exercise produced positive effects on weight gain in common carp, similar to earlier reports on trout and salmon (refer introduction). Thus, exercise can be implemented as a natural way of stimulating growth in aquaculture. Furthermore, expression of several growth related genes in hepatic tissue was up-regulated in fish swimming at $2.5 \mathrm{BL} / \mathrm{s}$ speed, confirming the growth stimulating effects of exercise. Despite the fact that GHR was elevated at the end of the trial at $1.5 \mathrm{BL} / \mathrm{s}$, the current study does not provide evidence of exercise-induced growth at $1.5 \mathrm{BL} / \mathrm{s}$. This is in contrast to salmonids that reportedly showed a significant increase in 
growth from sustained exercise ranging between 0.75 and $1.5 \mathrm{BL} / \mathrm{s}$ (Davison and Goldspink, 1977; Houlihan and Laurent, 1987; Jørgensen and Jobling, 1993). In salmonids, a relatively lower swimming speed for inducing growth might be attributed to their active ecotype with exercise being a core component of their routine behavioral repertoire (Jobling et al., 1993; Khan et al., 2014). Common carp are not such active swimmers, therefore a relatively higher swimming speed is required for any physiological or growth related changes (Tudorache et al., 2008b). Likewise in hapuku, which is also a less active swimmer, the growth promoting effect was detected at higher speeds (ca. 2.0 BL/ s) compared to migratory or highly active species such as salmonids (Khan et al., 2014). Conversely, swimming exercise (1.5, 3.0 and $4.5 \mathrm{BL} / \mathrm{s}$ ) did not augment weight gain in goldfish (Carassius auratus), another inactive swimmer belonging to Cyprinidae family (Davison and Goldspink, 1978). It is worth mentioning that Davison and Herbert (2013) and Martin and Johnston (2006) pointed out that ' $2.5 \mathrm{BL} / \mathrm{s}$ is a very high relative speed for a carp', but in our present study it was optimal for growth. Likewise, continuous exercise (0.9 and $2.1 \mathrm{BL} / \mathrm{s})$ did not boost the growth of flounder (Paralichthys olivaceus), another relatively inactive species (Ogata and Oku, 2000). To summarize this collective background, it is tempting to state that ecotype is an important factor determining the likelihood of exercise-induced growth. Also, fish farmers may be inclined to consider swimming ecotype as the most valid indicator of success for exercise-induced growth. However, Chinook salmon (Oncorhynchus tshawytscha) and Atlantic cod (Gadus morhua), species that both have active ecotypes, did not grow faster in response to exercise (Kiessling et al., 1994; Bjørnevik et al., 2003; Hoffnagle et al., 2006; Karlsen et al., 2006). Therefore, our results on common carp along with these findings on chinook salmon and Atlantic cod reinforce that ecotype and/or general level of active swimming should not be considered as predicting factor for the likelihood of improved growth induced by exercise in aquaculture. Also, it is reasonable to assume that swimming mediated growth is dependent on speciesspecific preference for $\mathrm{ER}_{\text {opt growth }}$ (or $\mathrm{U}_{\mathrm{opt}}$ ). Results obtained in the present study seem to be in disagreement with an earlier study evaluating the effects of sustained swimming on common carp. Martin and Johnston (2006) used similar swimming speeds (2.4-2.6 BL/s) for sustained swimming for 28 days and did not observe improved growth. However, fish used in their study were not juveniles, and with a body mass 20 times greater than fish from our study, it might have been hard to pick up subtle differences in growth rates within this time frame. On the other hand, common carp with similar size as the current study were used in study of He et al. (2013), but the training speed was much higher at 7.5 BL/s which is at or slightly above the $\mathrm{U}_{\text {crit }}$ we found here. It is worth mentioning that experimental protocols in both studies did not include constant (whole day) exercise. Instead, Martin and Johnston (2006) trained fish for $16 \mathrm{~h}$ per day, while He et al. (2013) trained common carp for $6 \mathrm{~h}$ per day. Comparing the results from various fish swimming experiments is extremely complicated due to differences in the experimental protocols and facilities, but we argue that continuous swimming at approximately $1 / 3$ rd of their $U_{\text {crit }}$ provided fish with optimal rearing conditions allowed for increased growth.

While the setting of optimal exercising regime is important for growth, however, another important factor could be the duration of sustained swimming. Under the present experimental conditions, a relatively short training period (1 week) showed stimulation of growth. Similarly, Grim et al. (2010) demonstrated that swimming training for 9 days enhanced the growth in killifish (Fundulus heteroclitus), while 14 days of continuous exercise promoted weight gain in darkbarbel catfish (Peltebagrus vachelli) and Atlantic salmon (Liu et al., 2009; Anttila et al., 2011). However, in larger aquaculture-type settings (e.g., commercial aquaculture ponds, in-pond raceways) the training tends to be longer, usually several months or longer (Bugeon et al., 2003; Karlsen et al., 2006; Arbeláez-Rojas and Moraes, 2010).

\subsection{Modulation of GH/IGF-I axis}

We investigated whether the gene expression patterns of growth regulating hormones and receptors (GH, IGF-I, GHR and SL) altered when fish were subjected to different exercise regimes. In general, these hormones act in concert to promote growth and their secretion patterns are influenced by physiological or environmental factors. However, the effects of exercise on the GH/IGF-I axis are not well known. Temporal assessment shows that IGF-I and GHR expression was up-regulated for $2.5 \mathrm{BL} / \mathrm{s}$ exercised fish in parallel with the rapid increase in weight gain (at the end of week 3 and 4). This suggests that the higher binding capacity of GH to the hepatic GH receptors, which is evident by the rise in the GHR mRNA level, induced the augmented growth. The amplified signal from the GHR potentially resulted in the elevation of mRNA transcript of IGF-I which ultimately promoted growth rate. Our observations agree with prior studies in gilthead sea bream juveniles wherein moderate exercise $(1.5$ and $5.0 \mathrm{BL} / \mathrm{s})$ increased plasma IGF-I levels (Sánchez-Gurmaches et al., 2013; Blasco et al., 2015). Although we measured only mRNA levels of GH/IGF-I axis, examining a correlation between mRNA levels and their corresponding protein may be crucial in future experiments. Furthermore, available literatures on salmonids and some non-salmonid teleosts (killifish and striped bass Morone saxatilis) suggest that the GH/IGF-I axis has an iono-osmoregulatory function (Mancera and McCormick, 1998; McCormick, 2001). We did not find a disturbance in iono-regulation in common carp, but possibly the lower muscle water content in exercised fish could be linked to the stimulation of the GH/IGF-I axis.

In addition to gene expression, other body indices such as hepatosomatic index (HSI) also increased in fish reared at $2.5 \mathrm{BL} / \mathrm{s}$. HSI is an indirect biomarker of growth rate and energy balance of hepatic metabolism (Jobling, 2001). Increases in HSI have been shown in Chinook salmon exercising at a speed of $1.5 \mathrm{BL} / \mathrm{s}$ (Kiessling et al., 1994) and Atlantic cod swimming at $1.0 \mathrm{BL} / \mathrm{s}$ (Bjørnevik et al., 2003). In our study, higher HSI induced by $2.5 \mathrm{BL} / \mathrm{s}$ swimming regime also coincided with the elevated hepatic protein levels. This signifies an enhanced feed efficiency and improved nutritional status for $2.5 \mathrm{BL} / \mathrm{s}$ exercised fish, which eventually was reflected by lowered value for FCR as well as augmented weight gain \% and SGR. In addition, when calculating condition factor $\left(\mathrm{CF}=\left(\right.\right.$ Weight $/$ Length $\left.\left.^{3}\right) * 100\right)$ for week 4 , we also observed an increasing trend with swimming regimes with $\mathrm{CF}$ averaging $0.33,0.48$ and 0.53 respectively for control, 1.5 and $2.5 \mathrm{BL} / \mathrm{s}$ exercised fish.

\subsection{Effect of training on $U_{\text {crit }}$ aerobic metabolism and ammonia dynamics}

To evaluate any potential consequences of exercise on swimming capacity of fish, we employed a standard swimming trial to determine the critical swimming speed $\left(\mathrm{U}_{\text {crit }}\right)$. $\mathrm{U}_{\text {crit }}$ is extensively used in fish research to assess the swimming capacity of fish by increasing water speeds until the fish can no longer keep its position in the current and fatigues (Brett, 1964). Often, $U_{\text {crit }}$ is considered an important tool to evaluate the effects of biotic and abiotic factors on swimming capacity, and to make predictions about their physiological and metabolic fitness (Kieffer, 2010). Previous studies aimed to determine the $U_{\text {crit }}$ of common carp, which yielded various results. Tudorache et al. (2008b) and Yan et al. (2012) determined the $\mathrm{U}_{\text {crit }}$ for common carp of similar size to fish from present study to 8.8 and $8.9 \mathrm{BL} / \mathrm{s}$, respectively, which is slightly higher than our results. He et al. (2013) reported even higher values in the range from $9.5-10 \mathrm{BL} / \mathrm{s}$. Nonetheless, in other studies the $\mathrm{U}_{\text {crit }}$ for common carp were in intervals from $3.9 \mathrm{BL} / \mathrm{s}$ to $4.6 \mathrm{BL} / \mathrm{s}$ (De Boeck et al., 2006; Li et al., 2009; Liew et al., 2012). As previously mentioned, swimming performance depends on a number of factors, e.g. water temperature (Yan et al., 2012), length of flume (Tudorache et al., 2007a), and fish length (Tudorache et al., 2007b), which could explain such a high variation between results. In the present study, $\mathrm{U}_{\text {crit }}$ slightly decreased over time as fish grew bigger, but no effect of 
training was seen at any speed. In contrast, exercise-trained (13.0 BL/s) zebrafish showed significant increase in $U_{\text {crit }}$ (Palstra et al., 2010), thus zebrafish certainly appear to benefit by exercising at very high swimming speeds. Also, no training effect was seen inspecting our data on oxygen consumption rates. Fish that had been exercising at 1.5 and $2.5 \mathrm{BL} / \mathrm{s}$ did not consume higher amounts of oxygen compared to the control when swimming at equal speed in the respirometer. However, a training effect on ammonia excretion rates was obvious. Ammonia is the main waste product of protein catabolism in fish. During exercise, fish amplify their ammonia excretion rate (Alsop and Wood, 1997; Wicks et al., 2002; McKenzie et al., 2003; Sinha et al., 2012a), possibly induced by increases in plasma ammonia (Zhang et al., 2015). The number of ammonia excreting Rhesus glycoprotein can be increased by exercising fish (Zhang et al., 2015), explaining the occurrence of an elevated ammonia excretion rate. In our study, we only noticed a trend towards increased (numerical but not significant) Rhcg-a and Rhcg-b isoforms mRNA expression after 3 and 4 weeks of exercise. It seems that these responses succeeded in maintaining plasma $\mathrm{T}_{\mathrm{amm}}$ levels within control levels. High ammonia excretion following exercise is normally linked to an increase in protein catabolism. In our study, the $2.5 \mathrm{BL} / \mathrm{s}$ exercised fish group retained protein stores; although changes might be masked by the lower muscle water content. In fact, the lack of changes in metabolic fuels (proteins, lipids and glycogen) stored in the tissues is consistent with earlier results (Anttila et al., 2010; Blasco et al., 2015) and seems to indicate that energy demand for the swimming activity was fueled directly by a more efficient catabolism of dietary components, as is suggested by the improved FCR. This finding, together with higher HSI and hepatic protein level is in part supported by the work of Christiansen et al. (1989), who found a higher whole body protein level in exercised Arctic charr fry compared to control group. Nevertheless, the prioritization of energy store to sustain exercise activity in fish may vary with species, physiological state, seasonality, nutritional composition, and food intake (Magnoni et al., 2013).

\subsection{Expression pattern of stress related genes}

The generalized stress response at the cellular level is in part mediated by the actions of a family of proteins known as HSPs. The most extensively characterized of the heat shock proteins is a $70 \mathrm{kDa}$ protein (HSP70) and also the most commonly induced stress protein in response to suboptimal physiological conditions (Hutchinson et al., 1994; Iwama et al., 1998). It is very likely that intense exercise could lead to energy depletion, oxygen deprivation, generation of reactive oxygen species etc., which could potentially result in cellular damage and/or denatured proteins (Urso and Clarkson, 2003; Palstra and Planas, 2012) and thus signal the up-regulation of HSP as a protective mechanism. As no signs of energy depletion or oxygen deprivation were observed, a non-increment in HSP70 supports the lack of potential damage of proteins in case of 1.5 and $2.5 \mathrm{BL} / \mathrm{s}$ exercising speed.

One of the crucial hormones in the stress responses is cortisol, which has important role in glycogen deposition in liver (Wendelaar Bonga, 1997; McCormick, 2001). Moreover, if the blood levels of cortisol are chronically elevated, it impairs growth in fish (Pérez-Sánchez and Le Bail, 1999). The action of cortisol is mediated by high-affinity cortisol receptors (CR) primarily in the liver (Chakraborti et al., 1987; Maule and Schreck, 1990). The number and expression of hormone receptors are important factors for controlling the physiological response of the cells (Danielson and Stallcup, 1984; Vanderbilt et al., 1987). The expression of CR did not change between resting and exercising fish, again suggesting that 1.5 and $2.5 \mathrm{BL} / \mathrm{s}$ did not induce stress in the fish. Decreased resting plasma cortisol levels has been reported in exercised Atlantic salmon after a 28-day training period (Herbert et al., 2011), and in striped bass after 60 days of continuous swimming (Young and Cech Jr., 1994).

Similar to mammals, exercise is likely to induce oxidative stress in fish via the overproduction of reactive oxygen species (ROS) due to the increased mitochondrial oxidative activity (Urso and Clarkson, 2003; Pérez-Sánchez et al., 2011). Cytochrome oxidase (COI) can function as an antioxidant by either preventing the reduction in electron flow (Benzi et al., 1992) or by uncoupling electron transport from proton transfer (Richter, 1997). Up-regulated COI gene expression in fish exercised at $2.5 \mathrm{BL} / \mathrm{s}$ for 4 weeks could signify an induced adaptive response in attempting to neutralize the oxidative effect but considering the lack of indications of stress discussed above, an up-regulation of aerobic capacity is more likely. COI is also considered as the rate-limiting step for mitochondrial respiration (Villani and Attardi, 2000), and elevated expression of the COI gene could be a compensating mechanism to restore the mitochondrial activity and to efficiently consume oxygen (Achard-Joris et al., 2006). However, the direct relationship between COI expression and exercise in fish has not been studied extensively.

\section{Conclusion}

The results of the present study show that continuous swimming at $2.5 \mathrm{BL} / \mathrm{s}$ speeds leads to improved growth performance and feed conversion efficiency in common carp. Correspondingly, the expression kinetics of growth regulating hormone and receptor genes such as IGF-I and GHR were up-regulated by a $2.5 \mathrm{BL} / \mathrm{s}$ swimming speed. The augmented growth in $2.5 \mathrm{BL} / \mathrm{s}$ exercised fish was accompanied with an elevated HSI and lower MWC relative to the resting group. Fish were able to retain glycogen and lipid energy stores and increased HSI and protein deposition in the hepatic tissue. The tested exercising speeds did not elicit stress in fish, as seen by the expression pattern of HSP70, cortisol receptors and cytochrome oxidase. There were no training effects regarding oxygen consumption rates or swimming capacity but ammonia elimination was facilitated by exercise, which prevented an increase in plasma $\mathrm{T}_{\mathrm{amm}}$ accumulation. In brief, through this study we have determined $2.5 \mathrm{BL} / \mathrm{s}$ as a beneficial exercising speed for common carp, which can be taken into account for the improvement of sustainable aquaculture production. Nevertheless, currently there is an information gap addressing the exercise detraining effects in fish. The results obtained in this trial suggest that conducting long-term studies involving sustained swimming of fish is advised in the future, since most beneficial effects of exercise appeared only after a full three to four weeks.

\section{Acknowledgments}

The technical assistance of Khadija Kichouhi, Karin Van den Bergh, Marta Satorres Salvado, Dr. Freddy Dardenne, Steven Joosen and Nemo Maes is gratefully acknowledged. The authors would also like to thank Dr. Amit Kumar Sinha for the critical reading of the manuscript and the helpful suggestions. Jyotsna Shrivastava is a research fellow supported by a PhD Grant [BOF-DOCPRO-31444] from the University of Antwerp Research Council. This research is also supported by COST Action FA1304 "Swimming of fish and implications for migration and aquaculture (FITFISH).”

\section{References}

Achard-Joris, M., Gonzalez, P., Marie, V., Baudrimont, M., Bourdineaud, J.P., 2006. Cytochrome c oxydase subunit I gene is up-regulated by cadmium in freshwater and marine bivalves. Biometals 19, 237-244.

Alsop, D., Wood, C.M., 1997. The interactive effects of feeding and exercise on oxygen consumption, swimming performance and protein usage in juvenile rainbow trout (Oncorhynchus mykiss). J. Exp. Biol. 200, 2337-2346.

Anttila, K., Jäntti, M., Mänttäri, S., 2010. Effects of training on lipid metabolism in swimming muscles of sea trout (Salmo trutta). J. Comp. Physiol. B. 180, 707-714.

Anttila, K., Jokikokko, E., Erkinaro, J., Järvilehto, M., Mänttäri, S., 2011. Effects of training on functional variables of muscles in reared Atlantic salmon Salmo salar smolts: connection to downstream migration pattern. J. Fish Biol. 78, 552-566.

Arbeláez-Rojas, G., Moraes, G., 2010. Optimization of sustaining swimming speed of matrinxã Brycon amazonicus: performance and adaptive aspects. Sci. Agrár. 67, 253-258. 
Azuma, T., Noda, S., Yada, T., Ototake, M., Nagoya, H., Moriyama, S., Yamada, H., Nakanishi, T., Iwata, M., 2002. Profiles in growth, smoltification, immune function and swimming performance of 1-year-old masu salmon Oncorhynchus masou masou reared in water flow. Fish. Sci. 68, 1282-1294.

Béné, C., Barange, M., Subasinghe, R., Pinstrup-Andersen, P., Merino, G., Hemre, G.I., Williams, M., 2015. Feeding 9 billion by 2050 - putting fish back on the menu. Food Secur. 7, 261-274.

Benzi, G., Pastoris, O., Marzatico, R.F., Villa, R.F., Curti, D., 1992. The mitochondrial electron transfer alteration as a factor involved in the aging brain. Neurobiol. Aging $13,361-368$.

Bjørnevik, M., Karlsen, Ø., Johnston, I.A., Kiessling, A., 2003. Effect of sustained exercise on white muscle structure and flesh quality in farmed cod (Gadus morhua L.). Aquac. Res. 34, 55-64.

Blanchard, J.L., Watson, R.A., Fulton, E.A., Cottrell, R.S., Nash, K.L., Bryndum-Buchholz, A., Büchner, M., Carozza, D.A., Cheung, W.W.L., Elliott, J., Davidson, L.N.K., Dulvy, N.K., Dunne, J.P., Eddy, T.D., Galbraith, E., Lotze, H.K., Maury, O., Müller, C., Tittensor, D.P., Jennings, S., 2017. Linked sustainability challenges and trade-offs among fisheries, aquaculture and agriculture. Nat. Ecol. Evol. 1, 1240-1249.

Blasco, J., Moya, A., Millán-Cubillo, A., Vélez, E.J., Capilla, E., Pérez-Sánchez, J., Gutiérrez, J., Fernández-Borrás, J., 2015. Growth-promoting effects of sustained swimming in fingerlings of gilthead sea bream (Sparus aurata L.). J. Comp. Physiol. B. 185, 859-868.

Bligh, E.G., Dyer, W.J., 1959. A rapid method of total lipid extraction and purification. Can. J. Biochem. Physiol. 37, 911-917.

Bradford, M.M., 1976. A rapid and sensitive method for the quantitation of micro-gram quantities of protein utilizing the principle of protein-dye binding. Anal. Biochem. 72, 249-254.

Bradshaw, J.C., Kumai, Y., Perry, S.F., 2012. The effects of gill remodeling on transepithelial sodium fluxes and the distribution of presumptive sodium-transporting ionocytes in goldfish (Carassius auratus). J. Comp. Physiol. B. 182, 351-366.

Brett, J.R., 1964. The respiratory metabolism and swimming performance of young sockeye salmon. J. Fish. Res. Board Can. 21, 1183-1226.

Brown, E.J., Bruce, M., Pether, S., Herbert, N.A., 2011. Do swimming fish always grow fast? Investigating the magnitude and physiological basis of exercise-induced growth in juvenile New Zealand yellowtail kingfish, Seriola lalandi. Fish Physiol. Biochem. 37, 327-336.

Bugeon, J., Lefevre, F., Fauconneau, B., 2003. Fillet texture and muscle structure in brown trout (Salmo trutta) subjected to long-term exercise. Aquac. Res. 34, 1287-1295.

Chakraborti, P.K., Weisbart, M., Chakraborti, A., 1987. The presence of corticosteroid receptor activity in the gills of the brook trout, Salvelinus fontinalis. Gen. Comp. Endocrinol. 66, 323-332.

Christiansen, J.S., Jobling, M., 1990. The behaviour and the relationship between food intake and growth of juvenile Arctic charr, Salvelinus alpinus L., subjected to sustained exercise. Can. J. Zool. 68, 2185-2191.

Christiansen, J.S., Ringo, E., Jobling, M., 1989. Effects of sustained exercise on growth and body composition in first-feeding fry of Arctic charr, Salvelinus alpinus (L.). Aquaculture 79, 329-336.

Danielson, M., Stallcup, M.R., 1984. Down-regulation of glucocorticoid receptors in mouse lymphoma cell variants. Mol. Cell. Biol. 4, 449-453.

Davison, W., 1989. Training and its effects on teleost fish. Comp. Biochem. Physiol. A Mol. Integr. Physiol. 94, 1-10.

Davison, W., 1997. The effects of exercise training on teleost fish, a review of recent literature. Comp. Biochem. Physiol. A Mol. Integr. Physiol. 117, 67-75.

Davison, W., Goldspink, G., 1977. The effect of prolonged exercise on the lateral musculature of the brown trout (Salmo trutta). J. Exp. Biol. 70, 1-12.

Davison, W., Goldspink, G., 1978. The effect of training on the swimming muscles of the goldfish (Carassius auratus). J. Exp. Biol. 74, 115-122.

Davison, W., Herbert, N.A., 2013. Swimming-enhanced growth. In: Palstra, A.P., Planas, J.V. (Eds.), Swimming Physiology of Fish: Towards Using Exercise to Farm a Fit Fish in Sustainable Aquaculture, pp. 172-202 Berlin: Springer.

De Boeck, G., van der Ven, K., Hattink, J., Blust, R., 2006. Swimming performance and energy metabolism of rainbow trout, common carp and gibel carp respond differently to sublethal copper exposure. Aquat. Toxicol. 80, 92-100.

East, P., Magnan, P., 1987. The effect of locomotor activity on the growth of brook charr, Salvelinus fontinalis Mitchill. Can. J. Zool. 65, 843-846.

FAO, 2016. Fishery and Aquaculture Statistics [Aquaculture Production (Quantities and Values) 1950-2014] (FishStatJ). FAO Fisheries and Aquaculture Department.

Gallaugher, P.E., Thorarensen, H., Kiessling, A., Farrell, A.P., 2001. Effects of high intensity exercise training on cardiovascular function, oxygen uptake, internal oxygen transport and osmotic balance in Chinook salmon (Oncorhynchus tshawytscha) during critical speed swimming. J. Exp. Biol. 204, 2861-2872.

Grim, J.M., Miles, D.R.B., Crockett, E.L., 2010. Temperature acclimation alters oxidative capacities and composition of membrane lipids without influencing activities of enzymatic antioxidants or susceptibility to lipid peroxidation in fish muscle. J. Exp. Biol. 213, 445-452.

He, W., Xia, W., Cao, Z.D., Fu, S.J., 2013. The effect of prolonged exercise training on swimming performance and the underlying biochemical mechanisms in juvenile common carp (Cyprinus carpio). Comp. Biochem. Physiol. A Mol. Integr. Physiol. 166, 308-315.

Herbert, N.A., Kadri, S., Huntingford, F.A., 2011. A moving light stimulus elicits a sustained swimming response in farmed Atlantic salmon, Salmo salar L. Fish Physiol. Biochem. 37, 317-325.

Hoffnagle, T.L., Carmichael, R.W., Keniry, P.J., 2006. The effect of moderately increased and variable raceway flow rates on juvenile physiology, survival, and adult return of hatchery-reared Chinook salmon. Trans. Am. Fish. Soc. 135, 1567-1577.

Houlihan, D.F., Laurent, P., 1987. Effects of exercise training on the performance, growth, and protein turnover of rainbow trout (Salmo gairdneri). Can. J. Fish. Aquat. Sci. 44, $1614-1621$.

Hutchinson, K.A., Ditmar, K.D., Czar, M.J., Pratt, W.B., 1994. Proof that hsp70 is required for assembly of the glucorticoid receptor into a heterocomplex with hsp90. J. Biol. Chem. 269, 5043-5049.

Ibarz, A., Felip, O., Fernández-Borràs, J., Martín-Pérez, M., Blasco, J., Torrella, J.R., 2011 Sustained swimming improves muscle growth and cellularity in gilthead sea bream. J. Comp. Physiol. B. 181, 209-217.

Iwama, G.K., Thomas, P.T., Forsyth, R.B., Vijayan, M.M., 1998. Heat shock protein expression in fish. Rev. Fish Biol. Fish. 8, 35-56.

Jobling, M., 2001. Nutrient partitioning and the influence of feed composition on body composition. In: Houlihan, D., Boujard, T., Jobling, M. (Eds.), Food Intake in Fish. Blackwell Science Ltd, Oxford, pp. 354-375.

Jobling, M., Baardvik, B.M., Christiansen, J.S., Jørgensen, E.H., 1993. The effects of prolonged exercise training on growth performance and production parameters in fish. Aquac. Int. 1, 95-111.

Jørgensen, E.H., Jobling, M., 1993. The effects of exercise on growth, food utilization and osmoregulatory capacity of juvenile Atlantic salmon, Salmo salar. Aquaculture 116, 233-246.

Karlsen, Ø., Norberg, B., Kjesbu, O.S., Taranger, G.L., 2006. Effects of photoperiod and exercise on growth, liver size, and age at puberty in farmed Atlantic cod (Gadus morhua L.). ICES J. Mar. Sci. 63, 355-364.

Khan, J.R., Trembath, C., Pether, S., Bruce, M., Walker, S.P., Herbert, N.A., 2014 Accommodating the cost of growth and swimming in fish- the applicability of exercise-induced growth to juvenile hapuku (Polyprion oxygeneios). Front. Physiol. 5 , 448.

Kieffer, J.D., 2010. Perspective - exercise in fish: $50+$ years and going strong. Comp. Biochem. Physiol. A Mol. Integr. Physiol. 156, 163-168.

Kiessling, A., Higgs, D.A., Dosanjh, B.S., Eales, J.G., 1994. Influence of sustained exercise at two ration levels on growth and thyroid function of all-female Chinook salmon (Oncorhynchus tshawytscha) in seawater. Can. J. Fish. Aquat. Sci. 51, 1975-1984.

Kuipers, J., 1982. Salmon thrive on exercise. Fish Farmer 5, 9-10.

Leon, K.A., 1986. Effect of exercise on feed consumption, growth, food conversion, and stamina of brook trout. Prog. Fish Cult. 48, 43-46.

Li, D., Hu, W., Wang, Y., Zhu, Z., Fu, C., 2009. Reduced swimming abilities in fastgrowing transgenic common carp Cyprinus carpio associated with their morphological variations. J. Fish Biol. 74, 186-197.

Li, X.M., Yu, L.J., Wang, C., Zeng, L.Q., Cao, Z.D., Fu, S.J., Zhang, Y.G., 2013. The effect of aerobic exercise training on growth performance, digestive enzyme activities and postprandial metabolic response in juvenile qingbo (Spinibarbus sinensis). Comp. Biochem. Physiol. A Mol. Integr. Physiol. 166, 8-16.

Liew, H.J., Sinha, A.K., Mauro, N., Diricx, M., Blust, R., De Boeck, G., 2012. Fasting goldfish, Carassius auratus, and common carp, Cyprinus carpio, use different metabolic strategies when swimming. Comp. Biochem. Physiol. A Mol. Integr. Physiol. 163, 327-335.

Liu, Y., Cao, Z.D., Fu, S.J., Peng, J.L., Wang, Y.X., 2009. The effect of exhaustive chasing training and detraining on swimming performance in juvenile darkbarbel catfish (Peltebagrus vachelli). J. Comp. Physiol. B. 179, 847-855.

Magnoni, L.J., Felip, O., Blasco, J., Planas, J.V., 2013. Metabolic fuel utilization during swimming: optimizing nutritional requirements for enhanced performance. In: Swimming Physiology of Fish. Springer, Berlin, Heidelberg, pp. 203-235.

Mancera, J.M., McCormick, S.D., 1998. Osmoregulatory actions of the GH/IGF-I axis in non-salmonid teleosts. Comp. Biochem. Physiol. B Biochem. Mol. Biol. 121, 43-48.

Martin, C.I., Johnston, I.A., 2006. Endurance exercise training in common carp Cyprinu. carpio L. induces proliferation of myonuclei in fast muscle fibres and slow muscle fibre hypertrophy. J. Fish Biol. 69, 1221-1227.

Maule, A.G., Schreck, C.B., 1990. Glucocorticoid receptors in leukocytes and gill of juvenile coho salmon (Oncorhynchus kisutch). Gen. Comp. Endocrinol. 77, 448-455.

McCormick, S.D., 2001. Endocrine control of osmoregulation in teleost fish. Am. Zool. 41, 781-794.

McEwen, B.S., Wingfield, J.C., 2003. The concept of allostasis in biology and biomedicine. Horm. Behav, 43, 2-15.

McKenzie, D.J., Shingles, A., Taylor, E.W., 2003. Sub-lethal plasma ammonia accumulation and the exercise performance of salmonids. Comp. Biochem. Physiol. A Mol. Integr. Physiol. 135, 515-526.

McKenzie, D.J., Shingles, A., Claireaux, G., Domenici, P., 2008. Sublethal concentrations of ammonia impair performance of the teleost fast-start escape response. Physiol. Biochem. Zool. 82, 353-362.

Nahhas, R., Jones, N.V., Goldspink, G., 1982. Growth, training and swimming ability of young trout (Salmo gairdneri R.) maintained under different salinity conditions. J. Mar. Biol. Assoc. UK 62, 699-708.

Nakada, T., Westhoff, C.M., Kato, A., Hirose, S., 2007. Ammonia secretion from fish gill depends on a set of Rh glycoproteins. FASEB J. 21, 1067-1074.

Navarro, I., Capillas, E., Castillo, J., Albalat, A., Díaz, M., Gallardo, M.A., Blasco, J., Planas, J.V., Gutiérrez, J., Reinecke, M., Zaccone, G., Kapoor, B.G., 2006. Insulin metabolic effects in fish tissues. In: Reinecke, M., Zaccone, G., Kapoor, B.G. (Eds.), Fish Endocrinology. 1. Science Publishers, Enfield, NH, pp. 15-48.

Nawata, C.M., Hung, C.C.Y., Tsui, T.K.N., Wilson, J.M., Wright, P.A., 2007. Ammonia excretion in rainbow trout (Oncorhynchus mykiss): evidence for Rh glycoprotein and $\mathrm{H}^{+}$-ATPase involvement. Physiol. Genomics 31, 463-474.

Nunes, C.D.S., Moraes, G., Fabrizzi, F., Hackbarth, A., Arbeláez-Rojas, G.A., 2013. Growth and hematology of pacu subjected to sustained swimming and fed different protein levels. Pesq. Agropec. Bras. 48, 645-650.

Ogata, H.Y., Oku, H., 2000. Effects of water velocity on growth performance of juvenile Japanese flounder Paralichthys olivaceus. J. World Aquacult. Soc. 31, 225-231.

Onukwufor, J.O., Wood, C.M., 2018. The osmorespiratory compromise in rainbow trout 
(Oncorhynchus mykiss): the effects of fish size, hypoxia, temperature and strenuous exercise on gill diffusive water fluxes and sodium net loss rates. Comp. Biochem. Physiol. A Mol. Integr. Physiol. 219, 10-18.

Palstra, A.P., Planas, J.V., 2011. Fish under exercise. Fish Physiol. Biochem. 37, 259-272. Palstra, A.P., Planas, J.V.eds., 2012. Swimming Physiology of Fish: Towards Using Exercise to Farm a Fit Fish in Sustainable Aquaculture. Springer Science \& Business Media.

Palstra, A., van Ginneken, V., van den Thillart, G., 2008. Cost of transport and optimal swimming speed in farmed and wild European silver eels (Anguilla anguilla). Comp. Biochem. Physiol. A Mol. Integr. Physiol. 151, 37-44.

Palstra, A.P., Tudorache, C., Rovira, M., Brittijn, S.A., Burgerhout, E., van den Thillart, G.E., Spaink, H.P., Planas, J.V., 2010. Establishing zebrafish as a novel exercise model: swimming economy, swimming-enhanced growth and muscle growth marker gene expression. PLoS One 5, p.e14483.

Palstra, A.P., Beltran, S., Burgerhout, E., Brittijn, S.A., Magnoni, L.J., Henkel, C.V., Jansen, H.J., Van Den Thillart, G.E., Spaink, H.P., Planas, J.V., 2013. Deep RNA sequencing of the skeletal muscle transcriptome in swimming fish. PLoS One 8, p.e53171.

Palstra, A.P., Mes, D., Kusters, K., Roques, J.A., Flik, G., Kloet, K., Blonk, R.J., 2015. Forced sustained swimming exercise at optimal speed enhances growth of juvenile yellowtail kingfish (Seriola lalandi). Front. Physiol. 5, 506.

Pérez-Sánchez, J., Le Bail, P.Y., 1999. Growth hormone axis as marker of nutritional status and growth performance in fish. Aquaculture 177, 117-128.

Pérez-Sánchez, J., Bermejo-Nogales, A., Calduch-Giner, J.A., Kaushik, S., Sitjà-Bobadilla, A., 2011. Molecular characterization and expression analysis of six peroxiredoxin paralogous genes in gilthead sea bream (Sparus aurata): insights from fish exposed to dietary, pathogen and confinement stressors. Fish Shellfish Immunol. 31, 294-302.

Reinecke, M., Zaccone, G., Kapoor, B.G., 2006. Insulin-like growth factor I and II in fish. In: Reinecke, M., Zaccone, G., Kapoor, B.G. (Eds.), Fish Endocrinology. 1. Science Publishers, Enfield, NH, pp. 87-130.

Richter, C., 1997. Reactive oxygen species and nitrogen species regulate mitochondrial $\mathrm{Ca}^{2+}$ homeostasis and respiration. Biosci. Rep. 17, 53-66.

Roe, J.H., Dailey, R.E., 1966. Determination of glycogen with the anthrone reagent. Anal. Biochem. 15, 245-250.

Sánchez-Gurmaches, J., Cruz-Garcia, L., Ibarz, A., Fernández-Borrás, J., Blasco, J., Gutiérrez, J., Navarro, I., 2013. Insulin, IGF-I, and muscle MAPK pathway responses after sustained exercise and their contribution to growth and lipid metabolism regulation in gilthead sea bream. Domest. Anim. Endocrinol. 45, 145-153.

Shingles, A., McKenzie, D.J., Taylor, E.W., Moretti, A., Butler, P.J., Ceradini, S., 2001. Effects of sublethal ammonia exposure on swimming performance in rainbow trout (Oncorhynchus mykiss). J. Exp. Biol. 204, 2691-2698.

Sinha, A.K., Liew, H.J., Diricx, M., Blust, R., De Boeck, G., 2012a. The interactive effects of ammonia exposure: nutritional status and exercise on metabolic and physiological responses in goldfish (Carassius auratus L.). Aquat. Toxicol. 109, 33-46.

Sinha, A.K., Diricx, M., Chan, L.P., Liew, H.J., Kumar, V., Blust, R., De Boeck, G., 2012b. Expression pattern of potential biomarker genes related to growth, ionregulation and stress in response to ammonia exposure, food deprivation and exercise in common carp (Cyprinus carpio). Aquat. Toxicol. 122-123, 93-105.

Sinha, A.K., Liew, H.J., Nawata, C.M., Blust, R., Wood, C.M., De Boeck, G., 2013. Modulation of Rh glycoproteins, ammonia excretion and $\mathrm{Na}^{+}$fluxes in three freshwater teleosts when exposed chronically to high environmental ammonia. J. Exp. Biol. 216, 2917-2930.

Totland, G.K., Kryvi, H., Jødestøl, K.A., Christiansen, E.N., Tangerås, A., Slinde, E., 1987. Growth and composition of the swimming muscle of adult Atlantic salmon (Salmo salar L.) during long-term sustained swimming. Aquaculture 66, 299-313.

Tudorache, C., Viaenen, P., Blust, R., De Boeck, G., 2007a. Longer flumes increase critical swimming speeds by increasing burst-glide swimming duration in carp Cyprinus carpio, L. J. Fish Biol. 71, 1630-1638.

Tudorache, C., Blust, R., De Boeck, G., 2007b. Swimming capacity and energetics of migrating and non-migrating morphs of three-spined stickleback Gasterosteus aculeatus L. and their ecological implications. J. Fish Biol. 71, 1448-1456.

Tudorache, C., Blust, R., De Boeck, G., 2008a. Social interactions, predation behaviour and fast start performance are affected by ammonia exposure in brown trout (Salmo trutta L.). Aquat. Toxicol. 90, 145-153.

Tudorache, C., Viaene, P., Blust, R., Vereecken, H., De Boeck, G., 2008b. A comparison of swimming capacity and energy use in seven European freshwater fish species. Ecol. Freshw. Fish 17, 284-291.

Urso, M.L., Clarkson, P.M., 2003. Oxidative stress, exercise, and antioxidant supplementation. Toxicology 189, 41-54.

Van Dijk, P.L.M., Van den Thillart, G.E.E.J.M., Bonga, S.W., 1993. Is there a synergistic effect between steady state exercise and water acidification in carp? J. Fish Biol. 42, 673-681.

Vanderbilt, J.N., Miesfeld, R., Maler, B.A., Yamamoto, K.R., 1987. Intracellular receptor concentration limits glucocorticoid dependent enhancer activity. Mol. Endocrinol. 1, 68-74.

Verdouw, H., Van Echteld, C.J.A., Dekkers, E.M.J., 1978. Ammonia determination based on indophenol formation with sodium salicylate. Water Res. 12, 399-402.

Villani, G., Attardi, G., 2000. In vivo control of respiration by cytochrome c oxidase in human cells. Free Radic. Biol. Med. 29, 202-210.

Walker, M.G., Emerson, L., 1978. Sustained swimming speeds and myotomal muscle function in the trout, Salmo gairdneri. J. Fish Biol. 13, 475-481.

Wendelaar Bonga, S.E., 1997. The stress response in fish. Physiol. Rev. 77, 591-625.

Wicks, B.J., Joensen, R., Tang, Q., Randall, D.J., 2002. Swimming and ammonia toxicity in salmonids: the effect of sub lethal ammonia exposure on the swimming performance of coho salmon and the acute toxicity of ammonia in swimming and resting rainbow trout. Aquat. Toxicol. 59, 55-69.

Wright, P.A., Wood, C.M., 2009. A new paradigm for ammonia excretion in aquatic animals: role of rhesus (Rh) glycoproteins. J. Exp. Biol. 212, 2303-2312.

Yan, G.J., He, X.K., Cao, Z.D., Fu, S.J., 2012. The trade-off between steady and unsteady swimming performance in six cyprinids at two temperatures. J. Therm. Biol. 37, $424-431$.

Yogata, H., Oku, H., 2000. The effects of swimming exercise on growth and whole body protein and fat contents of fed and unfed fingerling yellowtail. Fish. Sci. 66, 1100-1105.

Young, P.S., Cech Jr., J.J., 1993. Improved growth, swimming performance, and muscular development in exercise-conditioned young-of-the-year striped bass (Morone saxatilis). Can. J. Fish. Aquat. Sci. 50, 703-707.

Young, P.S., Cech Jr., J.J., 1994. Effects of different exercise conditioning velocities on the energy reserves and swimming stress responses in young-of-the-year striped bass (Morone saxatilis). Can. J. Fish. Aquat. Sci. 51, 1528-1534.

Zhang, L., Nurse, C.A., Jonz, M.G., Wood, C.M., 2011. Ammonia sensing by neuroepithelial cells and ventilatory responses to ammonia in rainbow trout. J. Exp. Biol. $214,2678-2689$.

Zhang, L., Nawata, C.M., De Boeck, G., Wood, C.M., 2015. Rh protein expression in branchial neuroepithelial cells, and the role of ammonia in ventilatory control in fish. Comp. Biochem. Physiol. A Mol. Integr. Physiol. 186, 39-51. 